Portland State University

PDXScholar

Dissertations and Theses

Dissertations and Theses

Summer 8-6-2018

\title{
Thietmar of Merseburg's Views on Clerical Warfare
}

Benjamin Joseph Wand

Portland State University

Follow this and additional works at: https://pdxscholar.library.pdx.edu/open_access_etds

Part of the Medieval History Commons, and the Military History Commons Let us know how access to this document benefits you.

\section{Recommended Citation}

Wand, Benjamin Joseph, "Thietmar of Merseburg's Views on Clerical Warfare" (2018). Dissertations and Theses. Paper 4540.

https://doi.org/10.15760/etd.6425

This Thesis is brought to you for free and open access. It has been accepted for inclusion in Dissertations and Theses by an authorized administrator of PDXScholar. Please contact us if we can make this document more accessible: pdxscholar@pdx.edu. 
Thietmar of Merseburg's Views on Clerical Warfare

$$
\text { by }
$$

\title{
Benjamin Joseph Wand
}

A thesis submitted for the partial fulfillment of the requirements for the degree of

\author{
Master of Arts \\ in \\ History
}

\section{Thesis Committee: \\ John S. Ott, Chair \\ Brian Turner \\ James Grehan \\ Steven Fuller}

Portland State University

2018 
C 2018 Benjamin Joseph Wand 


\begin{abstract}
The tenth-century German bishop was more than just a spiritual leader, he was also a territorial lord with secular power. These bishops also lived in an environment where violence was sometimes a way of life. His culture contained a social dynamic that saw violence as a tool for defending and maintaining honor and as a mechanism for dispute resolution. Therefore, some bishops behaved violently, either to defend their diocese from threats or to serve their own political intrigues. In some instances bishops were said to be more skilled in warfare than secular lords. However, while some clergy participated in warfare and violence, others sought to limit it through application of canon law and peacemaking. With some clergy participating in violence and others decreeing that it be banned, there were mixed messages regarding clerical violence in this era.

The bishop's role in warfare and violence, especially in Germany, has only been partially addressed by modern scholars. This deficit is part of an overall shortage of medieval German military scholarship. Furthermore, the historiography on bishops in the central Middle Ages (c. 900-1200) has generally covered two narratives: the bishop as a territorial lord or his role as a church reformer. This leaves a gap in scholarship that describes how an individual bishop justified or rationalized clerical participation in violence and warfare, including his own. This paper addresses that need by reporting how one German bishop, Thietmar of Merseburg (b. 975, 1009-18), reflected on and portrayed clerical violence and warfare in his Chronicon.

Thietmar's attitudes towards violence were as complex as the times in which he lived, and were influenced by his secularism and religiosity. When it came to his justifications for clerical violence and warfare, Thietmar was more concerned about the
\end{abstract}


clergyman's ability to perform as a military leader, and whether or not the violent actions were justified on their own merits. While he sometimes conveyed unease with some acts of clerical violence, and at times was careful to note distinctions between secular and spiritual realms, nevertheless he did not criticize a member of the clergy for violence on the basis of his religious station nor spiritual beliefs. Indeed, Thietmar was a torn individual, struggling with his religious convictions while living in a world where violence was habitual, and where he saw it as his duty to protect his flock. In this regard Thietmar should be considered a realist. 


\section{Dedication}

To my wife and children with gratitude.

To family, friends, and professors.

And most especially,

To it never being too late. 
Table of Contents

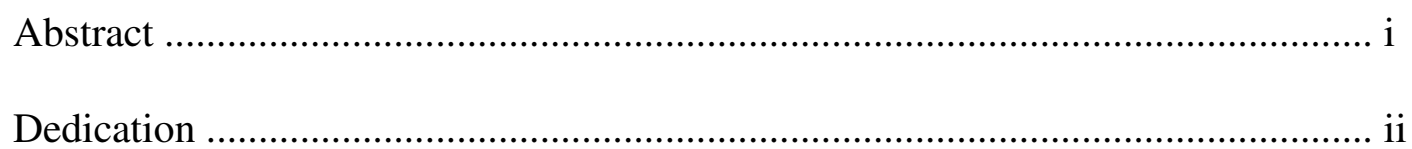

List of Tables .............................................................................................. iv

Chapter 1

Introduction: Setting the Stage ............................................................. 1

Chapter 2

Historiography: Medieval Bishops, Violence, and Cultural Context ..................... 13

Chapter 3

Source Analysis: Thietmar's Audience, Purpose, and Biography ......................... 31

Chapter 4

Investigation: Thietmar's Accounts of Clerical Violence ................................... 43

Chapter 5

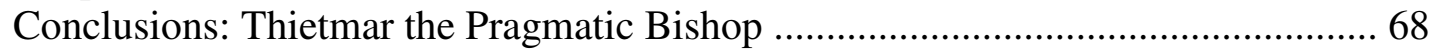

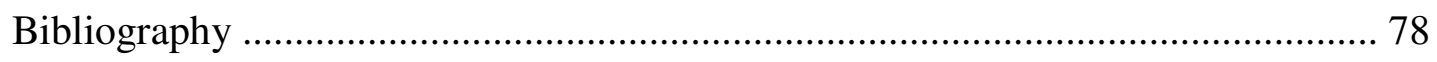


List of Tables

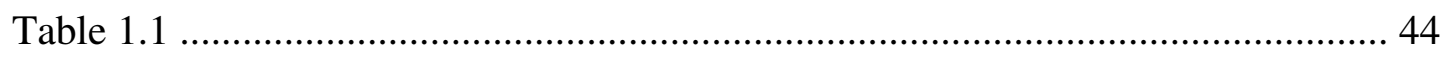




\section{Chapter 1}

\section{Introduction: Setting the Stage}

While facing rebellion from a group of his vassals in 1003, the new King Henry II of Germany (r. 1002-1024) sent two members of his clergy to destroy the burg Schweinfurt, located in Franconia. ${ }^{1}$ When they arrived at Schweinfurt the two clergyBishop Henry of Würzburg and Abbot Erkanbald of Fulda-disobeyed orders. Instead of destroying the burg with fire, they just removed the city walls by pulling them to the ground. ${ }^{2}$ The reasoning they used for disobeying their king and not utterly destroying the burg emphasizes a struggle they faced as men simultaneously holding spiritual and secular authority. According to chronicler and bishop Thietmar of Merseburg, when these two ecclesiastical lords arrived to carry out their mission, they experienced a change of heart:

When these lords arrived, Margrave Henry's revered mother, Eila by name, welcomed and greeted them, as was fitting for men of their station. When she understood the royal instructions, she became disturbed and hastened to the church in a rapid run. Once in that place, she testified that she would sooner be burned, along with the church, than to go out alive. Next, the aforementioned lords changed their orders on account of their love of Christ. They put behind them their worldly fears, breaking the walls of the city and buildings to the ground. With these promises they soothed the sad woman, that if it could be done with the king's favor, that they would rebuild this whole thing from their own share. ${ }^{3}$

\footnotetext{
${ }^{1}$ Robert Holtzmann, ed., Die Chronik des Bischofs Thietmar von Merseburg und ihre Korveier Überarbeitung, Monumenta Germaniae Historica, Scriptores Rerum Germanicarum (Berlin: Weidmannsche Buchhandlung, 1935), 264: "Misit tunc Heinricum, Wirciburgiensis [ecclesiae] episcopum, et Erkanbaldum, Fuldensis coenobii abbatem, ut Suinvordi castellum incenderent atque diruerent." David Warner, trans., Ottonian Germany: The Chronicon of Thietmar of Merseburg (New York: Manchester University Press, 2000), 230.

${ }^{2}$ Ibid., 264: “...murosque urbis ac aedifitia solotenus frangentes.” (English) Warner, trans., Ottonian Germany, 231.

${ }^{3}$ Ibid.: "Quos adventantes Heinrici comitis inclita mater Eila nomine, ut talibus decebat personis, suscipiens et salutans, ut precepta intellexit regalia, perturbatur concitoque cursu ad aeclesiam properans, ibidem ignis concremationem prius sustinere, quam hac comburente viva vellet exire, testatur. Unde
} 
This scene puts forth several issues which deserve further attention. One is the prominent place violence occupied in tenth-century German life, which is why this time is often called the 'Age of Iron'. 'Despite the Bible's message of peace and patience in the face of violence, this message was not practical to many, including the clergy. ${ }^{5}$ Some bishops participated in warfare while leading their own military retinues; others bore arms, fought in battles, and even earned martyrdom on the battlefield. Meanwhile other bishops and clergy played a more indirect role by blessing soldiers or performing religious rites before battles. This scene also highlights that Bishop Henry and Abbot Erkanbald, in addition to their positions in the church, served their king in a secular capacity. In fact, many bishops and other high-ranking clergy in this period held authority as both spiritual officials and secular lords. The drama in the above passage from Thietmar demonstrates the tensions men in these positions faced, which stemmed from their conflicting political commitments, religious duties, and personal convictions. Another issue is the fact that two high-ranking clergy were sent on a mission by their king to burn and destroy, a mission they accepted despite the fact that clerical armsbearing and violence were forbidden under canon law.

\footnotetext{
seniores prefati ob christi amorem seculares postponendo timores decretam mutabant sententiam; murosque urbis ac aedifitia solotenus frangentes, tristem matronam his mulcebant promissis, si quando cum gratia regis id fieri potuisset, hoc totum ex sua parte se renovaturos." (English) Warner, trans., Ottonian Germany, 231.

${ }^{4}$ Warner, trans., Ottonian Germany, 2. The term 'Age of Iron' and its use to characterize the ninth and tenth centuries as a transition period is under evaluation. See John Howe, 'Re-Forging the 'Age of Iron' Part I: The Tenth Century as the End of the Ancient World?” History Compass 8, no. 8 (2010): 866-887 and ibidem, "Re-Forging the 'Age of Iron' Part II: The Tenth Century in a New Age?" History Compass 8, no. 9 (2010): 1000-1022. The term 'Age of Iron' is used loosely in this study as useful shorthand, while recognizing its re-examination.

${ }^{5}$ Frederick H. Russell, The Just War in the Middle Ages (Cambridge: Cambridge University Press, 1975), 297.
} 
This condition resulted in a contradiction between secular and spiritual roles which scholars have characterized in a variety of ways, using terms such as 'warrior bishop' or 'militant bishop'. Despite this intuitive conflict between secular concerns and religious concerns, scholars have increasingly argued that bishops relied on combining military and political activities in order to provide better pastoral care for the members of their flock. ${ }^{6}$ In fact, bishops often benefitted through the intertwining of their secular and spiritual roles. ${ }^{7}$ Some bishops occasionally behaved violently, either to defend their diocese from threats or to serve their own political machinations. ${ }^{8}$ Bishops could also be drawn into violence through royal command. ${ }^{9}$ In some instances bishops were even said to be more skilled in warfare than secular lords. ${ }^{10}$ In this capacity, militant bishops contributed to the age's violence, even while attempting to temper it among lay nobles. ${ }^{11}$ Reading accounts of bishops leading armies to achieve their own political intrigues is perhaps disturbing and confusing to modern sensibilities. Furthermore, beyond this conflict between value systems, social norms, and individual behavior lie additional questions, such as how the militarization of the Church impacted what would

\footnotetext{
${ }^{6}$ Valerie Ramseyer, "Pastoral Care as Military Action: The Ecclesiology of Archbishop Alfanus I of Salerno (1058-1085)," in The Bishop Reformed: Studies of Episcopal Power and Culture in the Central Middle Ages, ed. John S. Ott and Anna Trumbore Jones (Aldershot: Ashgate, 2007), 206-207. See also the Introduction to Radosław Kotecki, Jacek Maciejewski, and John S. Ott, eds. Between Sword and Prayer: Warfare and Medieval Clergy in Cultural Perspective (Boston: Brill, 2018), .

${ }^{7}$ John Nightingale, "Bishop Gerard of Toul (963-94) and Attitudes to Episcopal Office," in Warriors and Churchmen in the High Middle Ages: Essays Presented to Karl Leyser, ed. Karl Leyser and Timothy Reuter (London: Hambledon Press, 1992), 41.

${ }^{8}$ Heinrich Fichtenau, Living in the Tenth Century: Mentalities and Social Orders, trans. Patrick J. Geary (Chicago: University of Chicago Press, 1991), 206.

${ }^{9}$ Lawrence G. Duggan, Armsbearing and the Clergy in the History and Canon Law of Western Christianity (New York: Boydell and Brewer, 2013), 109.

${ }^{10}$ Peter Clarke, "The Medieval Clergy and Violence: An Historiographical Introduction," in Violence and the Medieval Clergy, ed. Gerhard Jaritz and Ana Marinković (New York: Central European University Press, 2011), 7.

${ }^{11}$ Karl Leyser, "Early Medieval Warfare," in Communications and Power in Medieval Europe: The Carolingian and Ottonian Centuries ed. Timothy Reuter (London: Hambledon Press, 1994), 32-33.
} 
become acceptable behavior for its clergy, or what role an active and aggressive clergy played in secular military affairs. While some clergy participated in warfare and violence, others sought to limit it through canon law. In addition, the just war tradition was meant to regulate and guide the proper means and occasions for violence and warfare. With some clergy participating in violence and others decreeing that it be banned, mixed messages abound in this era. Finally, individual agency must be taken into account. People make choices, and those decisions are made within a social, moral, and legal setting. For a medieval bishop, this foundational background consisted of canon law, which forbade clerical armsbearing and violence. ${ }^{12}$ It also contained a social dynamic that saw violence as a tool for honor and as a mechanism for dispute resolution. ${ }^{13}$ While violence and warfare may not have been systemic during the Age of Iron, it was nonetheless part of life for most, especially for those who were secular lords. Since clerical armsbearing and violence was banned under canon law, ${ }^{14}$ how did German bishops justify their participation in these acts? What were their thoughts and feelings on the viciousness around them? And to what extent did their own actions contribute to violence?

The medieval German scholar Timothy Reuter emphasized the need to study sources on their own terms, ${ }^{15}$ with the goal of understanding them within their contexts, including their authors. ${ }^{16}$ Therefore, this paper's goal is to develop an understanding of how an individual medieval German bishop thought of clerical violence and warfare,

\footnotetext{
12 Duggan, Armsbearing and the Clergy, 100.

${ }^{13}$ Marc Bloch, Feudal Society, trans. Routledge Classics (Hoboken: Taylor and Francis, 2014), 432.

${ }^{14}$ Duggan, Armsbearing and the Clergy, 100.

15 Timothy Reuter, "Introduction: Reading the Tenth Century," in The New Cambridge Medieval History, Volume 3, c. 900 - c. 1024, ed. Timothy Reuter (Cambridge: Cambridge University Press, 1999 ), 14.

${ }^{16}$ Timothy Reuter, Germany in the Early Middle Ages (London: Longman, 1991), 7.
} 
using Thietmar of Merseburg's Chronicon. What role did violence play in Thietmar's experience? Was he opposed to it, or indifferent? Did he participate in violent acts? How did Thietmar express his attitudes towards clerical violence in his Chronicon? Did he consider it good or bad? Finally, what can this tell us about the relationship between bishops and violence in this era? Answering these questions through the writings of Thietmar of Merseburg can help scholars develop a better understanding of the medieval German bishop as an individual in his social and cultural context. Painting this picture of Thietmar of Merseburg fulfills a critical need in modern scholarship, especially in Anglophone scholarship.

The bishop's role in warfare and violence, especially in Germany, has only been partially addressed by modern scholars. This deficit is part of an overall shortage of medieval German military scholarship. ${ }^{17}$ Many foundational studies that were written-on the German nobility, for instance-were completed during the Nazi period and are in need of updating. ${ }^{18}$ However, some modern work has been done on the interaction between the military and society, and especially on the rise of the German knighthood. ${ }^{19}$ Furthermore, the historiography on bishops in the central Middle Ages (c. 900-1200) has traditionally covered two narratives: the bishop as a territorial lord, or his role as a church reformer. ${ }^{20}$ Heinrich Fichtenau's overview of the tenth-century social structure contains a comprehensive chapter on bishops, detailing their political, secular, and spiritual

\footnotetext{
${ }^{17}$ David Stewart Bachrach, "The Military Organization of Ottonian Germany, c. 900-1018: The Views of Bishop Thietmar of Merseburg," The Journal of Military History 72, no. 4 (2008): 1061.

${ }^{18}$ John B. Freed, "Reflections on the Medieval German Nobility," The American Historical Review 91, no. 3 (1986): 573

${ }^{19}$ Bachrach, "The Military Organization of Ottonian Germany," 1064-1065.

${ }^{20}$ John S. Ott and Anna Trumbore Jones, "Introduction: The Bishop Reformed," in The Bishop Reformed: Studies of Episcopal Power and Culture in the Central Middle Ages eds. John S. Ott and Anna Trumbore Jones (Aldershot: Ashgate, 2007), 4-5.
} 
obligations. ${ }^{21}$ Yet Fichtenau's work provides a broad view of bishops as a whole, leaving out how individual bishops rationalized violence they saw or participated in. Stating that bishops were both secular and ecclesiastical lords, who had military retinues, participated in warfare, and managed their territories is a helpful generalization, but ultimately can not tell us how individual bishops thought about warfare and violence.

Studying how individual German bishops rationalized warfare and violence may lead to a greater understanding of how violence functioned in their society. It may help attribute more agency to people and their aggression, and also answer questions about how effective social institutions can be at curbing such behavior-or in fueling it. Questions of individual agency becomes more fascinating and complex in tenth-century Eastern Francia, because clerical armsbearing was against canon law. Understanding the roles that a German bishop played in violence and warfare, and the conditions, factors, and reasons given for this role may also help illuminate the cultural, social, and religious environment that he existed in.

The German bishop Thietmar of Merseburg (b. 975, r. 1009-18) and his Chronicon (1012-1018) contain many violent scenes that expose how he, as a militant Christian, ${ }^{22}$ viewed warfare and violence. Merseburg's location in a strategically important position along the north-eastern Frankish frontier required Bishop Thietmar to defend his borders against Slav incursions. ${ }^{23}$ This job put Thietmar in a position to command military forces, and his location provided a convenient staging area for King

${ }^{21}$ Fichtenau, Living in the Tenth Century, 199-216.

${ }^{22}$ Warner, trans., Ottonian Germany, 41.

${ }^{23}$ Ibid., 52. 
Henry II's campaigns into Poland and Bohemia. ${ }^{24}$ By examining how Thietmar recorded and described types of violence-especially when conducted by clergy-we can use his Chronicon to discover how he viewed clerical violence and warfare.

Thietmar and his Chronicon have been studied by some scholars in piecemeal fashion, yet there is no complete English study. Karl Leyser described the German study of Thietmar by Helmut Lippelt in 1973 problematic for a variety of reasons; one being his over-emphasis on texts other than the Chronicon. ${ }^{25}$ This situation puts Thietmar and his Chronicon in the foreground as a vast and significant primary source for early eleventh-century Germany. David Bachrach echoed this sentiment when he called Thietmar one of the best sources for military history in early medieval Germany, and used the Chronicon to model the military organization used by the German Ottonian royal line. ${ }^{26}$

Thietmar's attitudes towards violence were as complex as the times in which he lived, and reflect his secular and spiritual powers in an unofficial church-state political system, or Reichskirchensystem. ${ }^{27}$ When it came to clerical violence and warfare, Thietmar was concerned about the clergyman's ability to perform as a military leader, and whether or not the violent act was justified. Thietmar found feuding and rebellion generally wasteful and inexcusable, and preferred for warfare to occur in foreign lands or against foreign enemies. He also saw clerical violence as a means for earning praise or

\footnotetext{
${ }^{24}$ Warner, trans., Ottonian Germany, 60.

${ }^{25}$ Karl Leyser, "Lippelt, 'Thietmar von Merseburg Reichsbischof und Chronist' (Book Review)," English Historical Review 93, no. 366 (1978): 109-110.

${ }^{26}$ Bachrach, "The Military Organization of Ottonian Germany," 1066-1067.

${ }^{27}$ While the nature of the Reichskirchensystem is much debated, it is included here to mark its presence in the historiography of bishops and their political authority. See Timothy Reuter, "The "Imperial Church System' of the Ottonian and Salian Rulers: A Reconsideration," in Medieval Polities and Modern Mentalities, ed. Janet L. Nelson (Cambridge: Cambridge University Press, 2006), 325-354.
} 
honor, and for fulfilling clerical political and spiritual duties. However, Thietmar simultaneously portrayed unease with some acts of violence, and at times was careful to note the distinctions between the secular and spiritual realms. Analyzing Thietmar's views on violence and warfare requires an understanding of the tradition he inherited as a German noble and bishop in the early eleventh century, and an appreciation for the cultural, social, and political context in which he operated.

\section{Historical Background and Context in Germany c. 800-1000}

The tenth century was a challenging period in the region of East Francia (modern Germany). Consequently, scholars have attached various labels to it. One is its mischaracterization as a 'Dark Age, ${ }^{28}$ but even others, like 'Age of Iron' and 'Age of Obscurity' are also problematic according to Timothy Reuter. ${ }^{29}$ However, when examining the period and its violence, the term 'Age of Iron' seems an appropriate one to characterize a general condition, considering that warfare was the "primary and perennial occupation of society from the eighth to the eleventh centuries. ${ }^{, 30}$ Furthermore, this age saw a decline in legislative activity, ${ }^{31}$ and established authority was ineffective at curbing disorder or resolving disputes, "legitimate force was accepted as the natural means to reestablish order where other means had failed." ${ }^{32}$ Besides its violence, the 'long tenth century,' as it is also referred to, ${ }^{33}$ was a period of political transition, resulting in an

\footnotetext{
${ }^{28}$ Fichtenau, Living in the Tenth Century, $\mathrm{xv}$.

${ }^{29}$ Reuter, "Introduction: Reading the Tenth Century," 1-3.

${ }^{30}$ Leyser, "Early Medieval Warfare," 29.

${ }^{31}$ Reuter, "Introduction: Reading the Tenth Century," 6-7

${ }^{32}$ Fichtenau, Living in the Tenth Century, 417.

${ }^{33}$ Reuter, "Introduction: Reading the Tenth Century," 1.
} 
emerging monarchy and a regionally-focused church. Both of these nascent organizations combined with the nobility to form what Karl Leyser referred to as the "hierarchies of power," which were made up of dukes, margraves, and counts interacting through giftgiving and oaths with itinerant kings, who ruled and communicated by moving around. ${ }^{34}$ Ecclesiastical lords-including bishops and archbishops-played a prominent role in this structure. ${ }^{35}$ In addition, famine caused peasants to relocate to places where food was available, and secular and ecclesiastical lords were hard-pressed to feed, protect, and secure their people. ${ }^{36}$

Despite these obstacles, the tenth century was also a period for optimism. The frequent invasions from Hungarian Magyars and Vikings from the north decreased under Otto I, and a new monarchy emerged-the Ottonians-which forged East Francia into a promising German Empire. The Ottonian royal line was followed by the Salian line of German kings and emperors, and together they formed a string of rulers who incorporated and rekindled many Carolingian institutions and policies and promised a renewed Roman imperium.${ }^{37}$ Meanwhile, the Church continued its prominent role as regional administrative and legal establishment, working in tandem with the Ottonian rulers as a "state" institution.

In the early ninth century, the Carolingian king and emperor Charlemagne had established his realm over an area that encompassed modern France, the Low Countries, Italy north of Rome, and part of modern Germany. Known for his renovation of the

\footnotetext{
${ }^{34}$ Karl Leyser, Medieval Germany and Its Neighbours, 900-1250 (London: Hambledon Press, 1982), 4.

${ }^{35}$ Ibid., 4.

${ }^{36}$ Ibid., 1-4.

${ }^{37}$ See Timothy Reuter, "The Ottonians and Carolingian Tradition," in Medieval Polities and Modern Mentalities, ed. Janet L. Nelson (Cambridge: Cambridge University Press, 2006), 268-283.
} 
Christian church, development of a palace court at Aachen, and his successful military organization, Charlemagne's kingdom not only extended Frankish Christianity in a religious sense; it also relied upon his re-organized church system for imperial administration in a territorial sense, akin to Roman provinces. However, Charlemagne's unified empire did not last long. While Carolingian institutions and military organization continued beyond Charlemange's reign, his Holy Roman Empire had become divided into individual kingdoms after 817 during the reign of his successor, Louis the Pious (r. 814-840). The borders of these territories shifted over the following decades, as their Carolingian inheritors competed amongst themselves to extend their borders into other Carolingian kingdoms. By 843 Louis the German, ruler of East Francia, was facing raiding northmen, Magyars, and other threats on his eastern frontier, while also keeping an eye on the political aspirations of his brothers, Charles the Bald in West Francia and Lothar in the central kingdom. ${ }^{38}$

When the last Carolingian ruler in East Francia, Louis the Child, died (r. 900911), he was followed by Conrad I (r. 911-919), who was the first non-Carolingian king of the east Franks. ${ }^{39}$ King Henry I's (r. 919-936) subsequent election by East Frankish magnates established the reign of the Ottonian line of German kings. The Ottonian line became the cultural inheritors of the Carolingian kings. ${ }^{40}$ Henry I and his son Otto I (r. 936-973), secured their positions through significant military victories, much like their Carolingian predecessors, by defeating Hungarian raiders in 933 and later at the Battle at Lechfeld in 955, respectively. These victories served a dual purpose. First, they secured

\footnotetext{
${ }^{38}$ Rosamond McKitterick, The Frankish Kingdoms under the Carolingians, 751-987 (London: Longman, 1983), 169-175.

${ }^{39}$ Ibid., 307-308.

${ }^{40}$ Ibid., 301, 313.
} 
East Frankish borders in the east against further Hungarian incursions. Second, in a manner reminiscent of Charlemagne, Otto used his victory in 955 at the Lechfeld to prove his divine right to rule East Francia and secure his monarchy. ${ }^{41}$ Otto's claim to divine rule and its similarity to Charlemagne was not his only tie to his Carolingian forebears. Ottonian links to previous Carolingian ruling tradition were purposeful, and not only evoked tradition and memory, but the Ottonian political apparatus also leveraged Carolingian political, religious, and military institutions and policies. ${ }^{42}$

Although Henry I and Otto’s victories had solidified their borders against Danish, Slav, and Hungarian raiders, the newly founded Ottonian monarchs periodically faced rebellions from competing nobility. ${ }^{43}$ These rebellions were often lanched within their family-by sons and brothers-and demonstrated the tenuous power held by monarchs in the tenth century. Otto and his successors ruled medieval Germany in a theocratic fashion, through a church intertwined with the monarchy. German churches were given more powers, wealth, and political authority by the monarchy, even to the exent that bishops were appointed to manage territories (dioceses or sees), in place of familial noble appointments. ${ }^{44}$ The appointment of bishops as administrators of royal territories instead of secular nobles was meant to reduce the risk of revolts against the monarchy. It was only partially effective, but one consequence of this practice was that it upheld the prominent place that bishops enjoyed in medieval European society for centuries.

${ }^{41}$ Reuter, Germany in the Early Middle Ages, 160-161.

${ }^{42}$ Ibid., 148-150, 246.

${ }^{43}$ Ibid., 256.

${ }^{44}$ Leyser, Medieval Germany and Its Neighbours, 81. 
The bishop was a key figure in tenth-century German life. ${ }^{45}$ As a manager of his diocese, his responsibilities encompassed more than the spiritual care of his flock, and put him in a high position socially and politically. As both priest and noble, the bishop possessed spiritual duties as a member of the church, but as a territorial lord, he also administered his territory as part of the political structure. Therefore bishops-despite being part of the clerical class-were active participants in the 'feudalism' of the age and often had their own vassals, some for the purpose of providing military retinues. ${ }^{46}$ This situation posed conflicts for bishops and their churches, and the question of how Christians were supposed to defend themselves and their property challenged the church and its followers throughout this period. It also put clergy in a position to conduct violent acts, and may have encouraged clerical warfare. Indeed, bishops participated in feuds, defended their territory against rebels and invaders, and sometimes fought in battles.

${ }^{45}$ Ott and Jones, "Introduction: The Bishop Reformed," 1.

${ }^{46}$ Fichtenau, Living in the Tenth Century, 206-207. 


\section{Chapter 2}

\section{Historiography: Medieval Bishops, Violence, and Cultural Context}

The historiography of early medieval German clergy and violence is generally fragmented, and lacks a definitive study of clerical violence in all its dimensions. To achieve this task would require incorporating the political, social, cultural, legal, philosophical, and military components that created and supported the conditions which fostered clerical violence and warfare in early medieval Germany. This historiography covers existing themes regarding violence and warfare, in order to paint the landscape in which Thietmar of Merseburg existed, and help contextualize his commentary. Despite this historiography's length and depth, it will not cover all aspects that would factor into clerical violence and warfare. Indeed, some of those aspects have their own, rather extensive, historiographies. In those cases, one must select representative sources and portray a narrower narrative that represents the scholarship at large without losing sight of the overall goal of this study.

In 1971, Friedrich Prinz published one of the first examinations of clergy and warfare, Klerus und Krieg im Frühmittelalter: Untersuchungen zur Rolle der Kirche beim Aufbau der Königsherrschaft. Prinz followed clerical violence and warfare from the Merovingian era (ca. 500-751) to the Ottonian (ca. 919-1002), and concluded that clergy were enticed into warfare because of their social class and the institutions in which they participated. This image of clerical violence and warfare seems to place the clergy in a passive position in the face of social values and political institutions. His study was based on the premise that clerical participation in warfare, despite sitting in conflict with canon 
law, was a persistent feature in early medieval Germany. Bernard Bachrach considered this approach innovative, because Prinz went against traditional German scholarship by focusing on the divergence between how people were supposed to act, and how they really did. ${ }^{47}$ While Bachrach agreed with Prinz and his premise, he described Prinz' work as an accomplished beginning to a topic that required further investigation. ${ }^{48}$

Most recently, military historian David Bachrach has completed a study of religion's place in medieval warfare, and his articles on German military history in the period (c. 900-1100) are also useful in understanding warfare and its organization. ${ }^{49}$ Bachrach's 2003 monograph, Religion and the Conduct of War c. 300-1215, showed how Christian Roman soldiers in late antiquity adopted Christian thought and practices in order to allow them to fight and still follow Christianity. ${ }^{50}$ According to Bachrach, ecclesiastical and secular authorities continued this effort by further institutionalizing Christianity in the army, and by encouraging rites-such as penance-among Carolingian soldiers. ${ }^{51}$ After the Carolingians, with feuds and rebellions increasing the occurrence of warfare between Christians, Bachrach emphasized that this situation required that Christian soldiers be provided with greater justification for their violent acts, along with more assurance that their enemies were indeed evil. ${ }^{52}$ As evidence for his case, Bachrach demonstrated the wide variety of religious rites and rituals performed by clergy, before,

\footnotetext{
${ }^{47}$ Bernard Bachrach, "Klerus und Krieg im früheren Mittelalter. Untersuchungen zur Rolle der Kirche beim Aufbau der Königsherrschaft (Book Review)," The Catholic Historical Review 60, no. 3 (1974): 478-79.

${ }^{48}$ Friedrich Prinz, Klerus und Krieg im Frühmittelalter: Untersuchungen zur Rolle der Kirche beim Aufbau der Königsherrschaft (Stuttgart: Anton Hiersemann, 1971).

${ }^{49}$ David Stewart Bachrach, "The Military Organization of Ottonian Germany, c. 900-1018: The Views of Bishop Thietmar of Merseburg," The Journal of Military History 72, no. 4 (2008): 1061-1088.

${ }^{50}$ David Stewart Bachrach, Religion and the Conduct of War, c. 300-1215 (Woodbridge, UK: Boydell Press, 2003), 30-31.

${ }^{51}$ Ibid., 62-63.

${ }^{52}$ Ibid., 64.
} 
during, and after battle. Furthermore, clergy were ingrained as part of the army, even if their role was solely religious, and not military, in nature. While Bachrach aimed to describe the place that religious rituals, customs, beliefs, and practices played with organized warfare, he also described how Christianity's views on warfare evolved during the nine centuries he covered. ${ }^{53}$ One of the consequences of Christianity's continued justification for violence was that eventually the church branded justifiable homicide as a commendable act, as opposed to merely a sinful one. ${ }^{54}$ While it provides a critical piece in the study of Christian militarization and its justification for violence, Bachrach's monograph does not provide information regarding how individual clergy justified their own participation in violence as a combatant. ${ }^{55}$ Nevertheless, his monograph is unique in its coverage of how religious customs and practices were conducted by the clergy in order to provide spiritual relief for soldiers in battle.

In contrast to Prinz' focus on socio-political factors behind clerical violence and warfare, and Bachrach's study of religion in warfare, the anthology Violence and the Medieval Clergy (2002) examines 'private' clerical violence. In his introductory historiography on violence and the clergy, Peter Clarke summarized religious attitudes of and participation in 'public' warfare, but contrasted public warfare with private violence, in the form of feuding by nobles, and violent crimes (such as murder) committed against clergy. Citing Guy Halsall's study on medieval violence, ${ }^{56}$ Clarke concluded that private war, because it was not done for the common good, was considered illegitimate, and

\footnotetext{
${ }^{53}$ Bachrach, Religion and the Conduct of War, 2-3.

${ }^{54}$ Ibid., 107.

55 Ibid., 2-5.

${ }^{56}$ Guy Halsall, Violence and Society in the Early Medieval West (Woodbridge: Boydell, 2002).
} 
therefore unjust. ${ }^{57}$ However, its illegitimacy did not shield the clergy from being the victims, nor did it prevent clergy from participating in acts of violence. ${ }^{58}$

\section{A recent anthology, Between Sword and Prayer: Warfare and the Medieval} Clergy in Cultural Perspective (2018), contains essays on clerical warfare over a broad geographical range, and favors the period c. $1100-1200 .^{59}$ The editors introduce the topic by describing warfare as a pervasive activity and underscore the tensions this violence introduced in the clergy. The sources describe clergy as victims of warfare, through attacks on monasteries, churches, and cathedrals, or when clergy were killed or harmed. ${ }^{60}$ On the other hand, there are also contrasting examples in the sources that portray clergy not as passive bystanders, but as active participants. ${ }^{61}$ Ultimately, the root of clerical tension regarding warfare is that violence went against Christian ethics, even in cases of warfare against non-Christian infidels or during conversion, considered by some to be legitimate. ${ }^{62}$ This conflict between the reality of warfare and violence and Christianity's pacifistic ideals presented challenges to medieval writers, especially the clergy, who often showed their concern with this struggle by offering moral judgment on episodes of violence and warfare. ${ }^{63}$ Using their intellectual, legal, and Biblical mandate, clerics often passed judgment on warfare and those who conducted it, and were interested in

\footnotetext{
${ }^{57}$ Clarke, "The Medieval Clergy and Violence: An Historiographical Introduction," 8-9.

${ }^{58}$ Clarke, "The Medieval Clergy and Violence: An Historiographical Introduction," 8-9.

${ }^{59}$ Radosław Kotecki, Jacek Maciejewski, and John S. Ott, eds., Between Sword and Prayer: Warfare and Medieval Clergy in Cultural Perspective (Boston: Brill, 2018).

${ }^{60}$ Radosław Kotecki, Jacek Maciejewski, and John S. Ott, "The Medieval Clergy and War: A Historiographical Introduction," in Between Sword and Prayer: Warfare and Medieval Clergy in Cultural Perspective, eds. Radosław Kotecki, Jacek Maciejewski, and John S. Ott, 1-23 (Boston: Brill, 2018 ), 2.

${ }^{61}$ Ibid.

${ }^{62}$ Ibid., 3.

${ }^{63}$ Ibid., 2.
} 
determining whether or not they had conducted it lawfully or justly. ${ }^{64}$ In many cases, the outcome of warfare was determined to be God's will, and instances where God and his saints fought alongside warriors were not uncommon. ${ }^{65}$ In these cases, one is reminded that warfare and violence may have played a role in judicial ordeals. ${ }^{66}$ Some sources offered praise for arms-bearing clergy for acting as pastors to their flocks, ${ }^{67}$ a common ideal for ecclesiastics and one with a scriptural basis. These contradictions between the relationship between warfare, Christian ethics, and the clergy require more examination by scholars, especially in regards to the mentalities and thought of clerical writers and participants. $^{68}$

\section{Socio-Political Factors}

Bishops held a unique "sphere of authority within the political and social worlds of the Middle Ages. ${ }^{, 69}$ Tensions regarding clerical warfare and violence stemmed partly from the combined social and political position that bishops held-a position which gave them combined religious and secular authority. These prominent positions garnered bishops enough prestige and authority that Timothy Reuter equated a bishop's funeral with a modern state funeral. ${ }^{70}$ Many scholars have commented on the bishop's multi-

\footnotetext{
${ }^{64}$ Kotecki, Maciejewski, and Ott, “The Medieval Clergy and War: A Historiographical Introduction,” 2.

65 Ibid.

66 Ibid.

${ }^{67}$ Ibid., 3-4.

${ }^{68}$ Ibid., 4.

${ }^{69}$ John Eldevik, "Bishops in the Medieval Empire: New Perspectives on the Church, State and Episcopal Office," History Compass 9, no. 10 (2011): 776.

${ }^{70}$ Timothy Reuter, "A Europe of Bishops: The Age of Wulfstan of York and Burchard of Worms," in Patterns of Episcopal Power: Bishops in Tenth and Eleventh Century Western Europe = Strukturen Bischöflicher Herrschaftsgewalt im westlichen Europa des 10. und 11. Jahrhunderts, ed. Ludger Körntgen and Dominik Wassenhoven (Berlin: De Gruyter, 2011), 17-20.
} 
faceted role, which included a range of activities and duties: as shepherds, advisers, architects, generals, monastic founders, and not least, as savers of souls. ${ }^{71}$ One should not underestimate these facets of the bishop's responsibilities. An example of these duties is recorded in the Vita sancti Aethelwoldi, the life of Aethelwold, a tenth-century bishop of Winchester. ${ }^{72}$ His eccelesiastical virtues included helping and consoling orphans and widows, receiving pilgrims, defending the church, refreshing the poor, and setting "right those who had gone astray." ${ }^{, 73}$ Bishops were always teaching, and were responsible for their people's spiritual lives. ${ }^{74}$ Furthermore, their people seemed to expect firm commandments to guide them and saw the clergy as their "spiritual policemen." though the bishop was a religious figure associated with the church, making an assumption that a bishop was pious may cloud one's understanding that the "imperial bishop was first and foremost an administrator, statesman, and diplomat."76 Despite ecclesiastical concerns for their flock, bishops were often practical. ${ }^{77}$ Their skills in statesmanship and administration were often more desirable than piety. ${ }^{78}$

It may seem that a bishop should be focused on his spiritual, liturgical, and religious life, but the two roles bishops fulfilled-temporal and religious-were not seen as contradictory. Indeed, one scholar remarked that, "Historians have often exaggerated the

\footnotetext{
${ }^{71}$ Reuter, "A Europe of Bishops: The Age of Wulfstan of York and Burchard of Worms," 37.

72 Rosamond McKitterick, "The Church," in The New Cambridge Medieval History, Volume 3 c. $900-c$. 1024, ed. Timothy Reuter (Cambridge: Cambridge University Press, 1999), 143.

${ }^{73}$ Ibid., 143.

${ }^{74}$ Fichtenau, Living in the Tenth Century, 210.

75 Ibid., 305.

${ }^{76}$ C. Stephen Jaeger, "The Courtier Bishop in Vitae from the Tenth to the Twelfth Century," Speculum: A Journal of Medieval Studies 58, no. 2 (Apr., 1983): 293.

${ }^{77}$ McKitterick, "The Church," 152.

${ }^{78}$ Jaeger, "The Courtier Bishop in Vitae from the Tenth to the Twelfth Century," 294.
} 
supposed dichotomy between religious duties and political undertakings."79 In fact, both to the individuals in question and to scholars, the two roles were seen as complementary. ${ }^{80}$ Even though Karl Leyser said that some unease with this complementary view could be spotted in the sources, this was the thinking that formed scholarship for tenth- and eleventh-century Germany. ${ }^{81}$ Due to their grooming in the Ottonian royal chapel, German prelates especially have been characterized as 'courtier bishops. ${ }^{, 82}$ As such, these nobles were often praised for "their nobility of mind, spirit, and manners. ${ }^{\prime 83}$ Other qualities associated with the courtier bishop included episcopal beauty, education, and mores-which should be understood as personal behavior or character. ${ }^{84} \mathrm{~A}$ bishop who served his king was worthy of praise, even when that service involved supporting him militarily. ${ }^{85}$ Faithful service by a bishop in this manner was thought to support peace and justice. ${ }^{86}$ In his study on the tenth century, Heinrich Fichtenau explained that bishops not only shared virtues similar to the nobility, but also found them praiseworthy. ${ }^{87}$ Additionally, Fichtenau explained that: "Experience in warfare was listed among the 'good arts,' along with rhetorical skill and the art of advising." 88 Being a bishop often came with an obligation to provide military support to the kingdom or to participate in local political affairs, and bishops had their own vassals, some for the

\footnotetext{
${ }^{79}$ Ramseyer, "Pastoral Care as Military Action: The Ecclesiology of Archbishop Alfanus I of Salerno (1058-1085)," 207.

${ }^{80}$ Nightingale, "Bishop Gerard of Toul (963-94) and Attitudes to Episcopal Office," 41.

${ }^{81}$ Ibid., 41.

82 Jaeger, "The Courtier Bishop in Vitae from the Tenth to the Twelfth Century," 291-292.

${ }^{83}$ Ibid., 297.

${ }^{84}$ Ibid., 298-301.

${ }^{85}$ Nightingale, "Bishop Gerard of Toul (963-94) and Attitudes to Episcopal Office," 41.

${ }^{86}$ Ibid., 41.

${ }^{87}$ Fichtenau, Living in the Tenth Century, 197-198.

${ }^{88}$ Ibid., 408.
} 
purpose of providing them with military support. ${ }^{89}$ Military activity and political goals were seen as essentially religious, and might be necessary for the bishop to provide pastoral care. $^{90}$

Perhaps it is best to think of bishops in this period as quasi-independent rulers, ones with relatively few external obligations to the pope, archbishops, or the king. ${ }^{91}$ In this era the church performed an administrative function, organized around the Roman provincial model inherited from the Carolingians, yet the church had little central organization. ${ }^{92}$ In this model the old Roman province became the diocese, and its bishop acted as its provincial manager. ${ }^{93}$ This dynamic contributed to bishops having an increased interest in local and regional affairs, including politics. ${ }^{94}$ Indeed, the German monarchy was very active in church affairs, to the extent that this relationship could be described as theocratic. This was not unique to medieval Germany, however. Rulers who established or inherited kingdoms in the Carolingian imperium Romanum considered churches in their kingdom part of their domain, not only in the material sense by protecting churches and establishing new ones, but also through appointment of bishops and other clergy, mediating church disputes, and even assembling, conducting, and sometimes participating in church synods and councils, activities which produced official canon law. ${ }^{95}$

\footnotetext{
${ }^{89}$ Fichtenau, Living in the Tenth Century, 206-207.

${ }^{90}$ Ramseyer, "Pastoral Care as Military Action: The Ecclesiology of Archbishop Alfanus I of Salerno (1058-1085)," 207.

${ }^{91}$ Reuter, "A Europe of Bishops: The Age of Wulfstan of York and Burchard of Worms," 36.

${ }^{92}$ McKitterick, "The Church," 130-131.

93 Ibid.

94 Ibid.

${ }^{95}$ Gerd Tellenbach, The Church in Western Europe from the Tenth to the Early Twelfth Century (Cambridge: Cambridge University Press, 1993), 38.
} 
German scholars characterized these practices, and the use of bishops and archbishops as provincial lords, as an 'imperial church system', or Reichskirchensystem. Recently, the Ottonian-Salian Reichskirchensystem has been debated and scholars have moved away from this narrative. ${ }^{96}$ As a descriptor, the term seems to be valid-even if Reuter thought the term should be discarded-because the point of contention is that Germany's system was not unique when compared with similar church-state systems practiced in France and England. ${ }^{97}$ Furthermore, Reuter wrote that the Reichskirchensystem was an unhelpful generalization, which did not account for local and regional variance. ${ }^{98}$ However, Reuter accepted that bishops played a significant role in local politics, even if they were not official agents of empire. ${ }^{99}$ Another scholar, Rosamond McKitterick, agreed, and commented that politics "were a common theme" in bishop's lives, ${ }^{100}$ and portrayed bishops as active agents in a political power struggle against secular rulers, which resulted in a shifting power balance between religious and secular spheres. ${ }^{101}$

\section{A Culture of Violence}

The tenth- and eleventh-century German bishop operated in a culture known for its violence, feuding, and warfare. Partially this was due to regular raids from external threats such as Northmen and Magyars. However, internal feuding and rebellion also

\footnotetext{
${ }^{96}$ Eldevik, "Bishops in the Medieval Empire: New Perspectives on the Church, State and Episcopal Office," 776. For part of the debate, see Timothy Reuter, "The 'Imperial Church System' of the Ottonian and Salian Rulers: A Reconsideration," in Medieval Polities and Modern Mentalities, ed. Janet L. Nelson (Cambridge: Cambridge University Press, 2006), 325-354, and Rudolf Schieffer, "Der Ottonische Reichsepiskopat zwischen Königtum und Adel," Frühmittelalterliche Studien 23 (1989): 291-301.

${ }^{97}$ Reuter, “The 'Imperial Church System' of the Ottonian and Salian Rulers: A Reconsideration,” 353-354.

${ }^{98}$ Ibid., 353-354.

${ }^{99}$ Ibid., 343-344.

${ }^{100}$ McKitterick, "The Church," 144.

${ }^{101}$ Ibid., 134-135.
} 
played a significant role. While the traditional term for this era-the 'Age of Iron'-has been re-examined and potentially jettisoned, ${ }^{102}$ nevertheless the society is still described as having a culture of violence. ${ }^{103}$ In his analysis of the term 'Age of Iron', John Howe described the tenth century as one witnessing a "triumph of disorderly nobles, castellans, and knights" that would persist until at least the twelfth century. ${ }^{104}$ In place of a cohesive monarchy-one with increasing legitimacy and power and the ability to establish and enforce laws-the ninth- and tenth-century 'state government' succeeded in mitigating disorder "through elaborate public rituals, what German scholars have labeled 'rules of the game' (Spielregeln)." ${ }^{\prime 105}$ And this game was a competition for the acquisition of land, rewards, and honors, which lay at the heart of most of the rebellions and feuds at the time. ${ }^{106}$ Society was fiercely competitive and status was the focus of this struggle. ${ }^{107}$ The relatively weak government had difficulty enforcing an overall peace or orderly society, or a 'king's peace'. ${ }^{108}$ In this environment people took matters into their own hands. Disputes were integral to society ${ }^{109}$ and "legitimate force was accepted as the natural means to re-establish order where other means had failed."110 Therefore, violence was regular and somewhat pervasive.

\footnotetext{
${ }^{102}$ See John Howe, "Re-Forging the 'Age of Iron' Part I: The Tenth Century as the End of the Ancient World?" History Compass 8, no. 8 (2010): 866-887, and John Howe, "Re-Forging the 'Age of Iron' Part II: The Tenth Century in a New Age?" History Compass 8, no. 9 (2010): 1000-1022.

${ }^{103}$ Howe, "Re-Forging the 'Age of Iron' Part II: The Tenth Century in a New Age?" 1004.

${ }^{104}$ Ibid.

${ }^{105}$ Ibid.

${ }^{106}$ Leyser, Medieval Germany and Its Neighbours, 174.

${ }^{107}$ Wendy Davies and Paul Fouracre, "Conclusion: Property and Power in Early Medieval Europe," in Property and Power in the Early Middle Ages, eds. Wendy Davies and Paul Fouracre (New York: Cambridge University Press, 1995), 269.

${ }^{108}$ Reuter, Germany in the Early Middle Ages, 215.

${ }^{109}$ Warren C. Brown and Piotr Górecki, "What Conflict Means: The Making of Medieval Conflict Studies in the United States, 1970-2000," in Conflict in Medieval Europe: Changing Perspectives on Society and Culture, eds. Warren C. Brown and Piotr Górecki (Aldershot: Ashgate, 2003), 18.

${ }^{110}$ Fichtenau, Living in the Tenth Century, 417.
} 
Violence meant more than causing physical harm or destruction. There are also examples of non-physical violence in its psychological, verbal, and symbolic forms. ${ }^{111}$ In whatever form it took, exerting force and violence communicated power, announced a dispute publicly to the community, or became a negotiation tactic. ${ }^{112}$ While feuding often involved a reciprocation of violence, ${ }^{113}$ generally the tendency was towards material destruction instead of killing people. ${ }^{114}$ Generally, if violence took place in public, or if it was acknowledged publicly, then the violence would not incur consequences. ${ }^{115}$ Therefore, feuding in itself should not be seen as necessarily anarchic, disorderly, or unjust. ${ }^{116}$ In addition, the difference between 'warfare' and 'feuding' was simply a matter of scale. ${ }^{117}$ Warfare possessed a higher social position than lower-order violence, which would likely involve household servants or slaves. ${ }^{118}$ The ability to participate in warfare was a marker of one's higher social status, since the right to conduct war or limit violence was the king's function, ${ }^{119}$ and warriors were often highly valued. ${ }^{120}$

Theoretically, among the three social orders traditionally ascribed to medieval Europe-peasants, clergy, and nobles-the relatively small aristocracy held a monopoly on military force and its use, and was characterized by a mounted military force. ${ }^{121}$ German scholars went so far as to say that all classes had a right to self-defense, but that by the

\footnotetext{
${ }^{111}$ Halsall, Violence and Society in the Early Medieval West, 34.

112 Ibid., 11-34.

113 Ibid., 19.

${ }^{114}$ Fichtenau, Living in the Tenth Century, 418-419.

${ }^{115}$ Halsall, Violence and Society in the Early Medieval West, 15.

${ }^{116}$ Fichtenau, Living in the Tenth Century, 418.

${ }^{117}$ Ibid., 418.

${ }^{118}$ Halsall, Violence and Society in the Early Medieval West, 30.

119 Ibid., 30.

${ }^{120}$ Bloch, Feudal Society, 305.

${ }^{121}$ David Stewart Bachrach, "Milites and Warfare in Pre-Crusade Germany," War in History 22, no. 3 (2015): 300 .
} 
twelfth century, farmers had lost their right to participate in offensive military campaigns. ${ }^{122}$ However, nearly every facet of the social order at this time was a byproduct of violence. ${ }^{123}$ Most medieval German bishops came from the aristocracy, which was a social class that took pride in its martial abilities. ${ }^{124}$ Despite the Gospel's teachings and the training most bishops received in their childhood, "it is not perhaps surprising that bishops retained the nobleman's instinct as bellatores when they became oratores." 125

Amidst these social and cultural conditions, bishops and clergy existed in a real world: one where men lived in a state of insecurity, plundering was a viable economic option, and personal honor was often proven on the battlefield. ${ }^{126}$ In addition to feuding and competition for praise and honors, regular Norse, Magyar, and Saracen raids made war "a grinding fact of life" for the clergy-especially bishops and abbots-who soon took part in warfare and violence. ${ }^{127}$ In this environment it should not be surprising that some pragmatically-minded clergy claimed a right to self-defense, especially when secular authority failed to protect them. ${ }^{128}$ Yet, some bishops participated in violence that went well beyond self-defense. ${ }^{129}$ Sometimes their participation was mandatory, through orders by royalty or in order to defend their possessions from attack. ${ }^{130}$ But clergy also went on the offensive and attacked others. Indeed, according to Fichtenau, "clerics had

\footnotetext{
${ }^{122}$ Bachrach, "Milites and Warfare in Pre-Crusade Germany," 303.

${ }^{123}$ Halsall, Violence and Society in the Early Medieval West, 30.

${ }^{124}$ Benjamin Arnold, "German Bishops and their Military Retinues in the Medieval Empire," German History 72, no. 2 (1989): 161.

${ }^{125}$ Ibid., 161.

${ }^{126}$ Bloch, Feudal Society, 431-432.

${ }_{127}$ Duggan, Armsbearing and the Clergy, 108-109.

${ }^{128}$ Russell, The Just War in the Middle Ages, 298.

${ }^{129}$ Fichtenau, Living in the Tenth Century, 207.

${ }^{130}$ Duggan, Armsbearing and the Clergy, 108-109.
} 
little trouble making the language of blood feud their own." ${ }^{\prime 31}$ Bishops had their own vassals; some for the purpose of providing military retinues, and even bore weapons during their military activity. ${ }^{132}$ The actions of these militant bishops had other, more farreaching consequences for medieval Germany. Militant bishops played an active role along with territorial lords in bolstering a specialized warrior class, which eventually became the German knighthood. ${ }^{133}$ Secondly, militant bishops who sought lands and honors caused tensions that impacted future church reform movements. ${ }^{134}$

\section{Church Responses to Violence: Canon Law and Just War}

Even though violence and warfare may have been regular events in early medieval Germany, one should not think of this period as one full of anarchy, because peace was the norm. ${ }^{135}$ Furthermore, while members of the clergy often participated in violence, Christianity's influence did play a role in restricting the amount of murder and killing that occurred. ${ }^{136}$ But the church's position towards violence and warfare was fluid, and transformed significantly around the turn of the millennium. ${ }^{137}$ This turn came when the church opened its arms to warriors, militia Christi, who could fight in service of the church or to protect the weak, and the church declared that soldiers of Christ who did so

\footnotetext{
${ }^{131}$ Fichtenau, Living in the Tenth Century, 423.

${ }^{132}$ Ibid., 206-207.

${ }^{133}$ See Benjamin Arnold, German Knighthood, 1050-1300 (New York: Clarendon Press, 1985).

${ }^{134}$ Benjamin Arnold, "Episcopal Authority Authenticated and Fabricated: Form and Function in Medieval German Bishops' Catalogues," in Warriors and Churchmen in the High Middle Ages: Essays Presented to Karl Leyser, ed. Karl Leyser and Timothy Reuter (London: Hambledon Press, 1992), 62.

${ }^{135}$ Fichtenau, Living in the Tenth Century, 423.

${ }^{136}$ Ibid., 427.

${ }^{137}$ Carl Erdmann, The Origin of the Idea of Crusade, trans. Marshall W. Baldwin and Walter Goffart (Princeton: Princeton University Press, 1977), 57.
} 
were performing a religious duty. ${ }^{138}$ Part of this transition was a response to its members' participation in this behavior, and another part was the "withdrawal of royal protection," which led to social insecurity. ${ }^{139}$

From its beginnings in the Roman Empire, the Christian Church struggled to remedy biblical inconsistencies regarding warfare. While the Bible said that killing was a sin, biblical references to the words and deeds of Joshua and Jesus seemed to allow the existence of Christian warriors. ${ }^{140}$ In response to these contradictions, efforts were made to rationalize and justify war and violence using scripture. After decades of debate by bishops like Ambrose and Augustine, Gratian concluded that if men had to fight, then they should follow the rules of just war. ${ }^{141}$ These rules were defined by the intention of those fighting; such as, was the goal based on love or justice? Or was the violence tapping into sinful feelings of greed, revenge, or pleasure? Under these qualifications, a just war became "normative" over the hostile act. ${ }^{142}$ Proper warfare customs evolved, which included boasting and insults with the intent to dehumanize the enemy, and soldiers were supposed to maintain their aggression using discipline during conflicts. ${ }^{143}$ However, these "rules" for just war were hardly consistent. For example, a soldier fighting under a prince was assumed to be fighting for favor, therefore if he killed someone on purpose, the soldier was acting "contrary to God's command." ${ }^{144}$ But if a legitimate prince fought for peace, his actions were considered just and he was not acting

\footnotetext{
${ }^{138}$ Erdmann, The Origin of the Idea of Crusade, 57.

${ }^{139}$ Ibid., 59. Also, Erdmann's position is that the Church's justification for holy war was created after the fact. See Erdmann, 80.

${ }^{140}$ Russell, The Just War in the Middle Ages, 9-11.

141 Ibid., 12.

142 Ibid., 17.

${ }^{143}$ Fichtenau, Living in the Tenth Century, 418.

${ }^{144}$ Erdmann, The Origin of the Idea of Crusade, 80.
} 
against God. ${ }^{145}$ Over time this development allowed war to be used as a means of formal conflict resolution. ${ }^{146}$ In the case of murder and private violence, there was no justification and there are records of perpetrators asking for forgiveness after their crimes. ${ }^{147}$

Penance was one method bishops and clergy used to help themselves navigate through the real-world violence they sometimes faced. Carolingian ecclesiastics formalized types of atonement to introduce habits of confession and penance within the army. ${ }^{148}$ While there were no formal church doctrines recorded until the Investiture Controversy, there were writings that outlined penance requirements for soldiers who fought. ${ }^{149}$ Over time penitential practices evolved into formal prayers and rituals conducted by clergy before battles, the use of relics on the battlefield, and formal donations of lands and spoils of war to monasteries and the Church. ${ }^{150}$ Soldiers who served a prince and killed in the prince's just war had to perform penance of three times forty days, "but whoever does so without a prince's command must do penance as though for a murder." ${ }^{\prime 151}$ These penitential practices show that the secular nobility and the clergy took their spiritual lives seriously, at least to some degree. In addition, clerical blessings, prayers, and the use of relics placed these spiritual leaders on the battlefield, even if they did not directly commit violence.

While just war doctrine provided scriptural justification for warfare, canon law maintained that clerical armsbearing and warfare was forbidden. In terms of church

\footnotetext{
${ }^{145}$ Erdmann, The Origin of the Idea of Crusade, 80.

${ }^{146}$ Russell, The Just War in the Middle Ages, 19.

${ }^{147}$ Clarke, "The Medieval Clergy and Violence: An Historiographical Introduction," 8-9.

${ }^{148}$ Bachrach, Religion and the Conduct of War, 62.

${ }^{149}$ Erdmann, The Origin of the Idea of Crusade, 80.

${ }^{150}$ Bachrach, Religion and the Conduct of War, 62-65.

${ }^{151}$ Erdmann, The Origin of the Idea of Crusade, 80.
} 
doctrine and attitudes, the tenth century was a transition period between the Carolingian and the Gregorian models. ${ }^{152}$ Consequently, there were few official guidelines, canons, or formal institutions which would have restricted ecclesiastical behavior. A few synods occurred, which were often attended by German kings or emperors, but were generally gathered to address specific issues in the time and place where the synod was conducted. ${ }^{153}$ But one, the Synod of Hohenalteim (916), contained passages on how to be a Christian bishop and how to protect the privilege of the Church. ${ }^{154}$ This synod may be an example of how Carl Erdmann described the church becoming "intertwined" with violence and warfare during the tenth century. ${ }^{155}$ Furthermore, eleventh-century church reforms specifically addressed clerical violence and armsbearing. Beginning in 1049 with Pope Leo IX's council at Reims-some forty years after Thietmar's day-eleven councils or synods over the next thirty years condemned clerical armsbearing. ${ }^{156}$ These rulings were repeated by Pope Urban II at the council of Clermont in 1095, and again at Reims in 1119 by Pope Calixtus II. ${ }^{157}$ Two versions of the first decree at Reims can be read today, are specifically worded, and extend beyond armsbearing: "Clerics are not to bear arms" and "No one of the clergy is to carry weapons or serve in the secular military forces."158 In addition to the stipulation that clergy should not bear arms, some synods decreed that it was a sin for a Christian to spill the blood of another Christian. ${ }^{159}$

\footnotetext{
152 McKitterick, "The Church," 153.

${ }^{153}$ Ibid., 154-155.

${ }^{154}$ Ibid., 135.

${ }^{155}$ Erdmann, The Origin of the Idea of Crusade, 59.

${ }^{156}$ Duggan, Armsbearing and the Clergy, 99.

157 Ibid.

${ }^{158}$ Duggan, Armsbearing and the Clergy, 100.

${ }^{159}$ Ibid.
} 
After years of defending against attacks and raids from pagan Northmen and Magyars, the Church associated this defense with the justice of the Christian cause, and in turn this attitude became a key component of the idea of holy war in the ninth and tenth centuries. ${ }^{160}$ Gradually this defensive stance became offensive. ${ }^{161}$ On the eastern German frontier, where bishops and clergy were in the process of converting sometimes hostile pagans to Christianity, violence against heathens who resisted conversion may have been justified. ${ }^{162}$ However, not all conversion activities on the German frontiers had to come to violence. Indeed, bishops and missionaries operated within a spectrum of justified violence, where pagans who converted easily were allowed to do so without undue harm. As Gerd Tellenbach explained, conversion violence contained nuance and complexity, depending upon the severity of the target's transgression against the Christian God. ${ }^{163}$ In addition, the results of military conflict mattered. Military defeat was explained as God's judgment against sins committed by the army, the people, or its leader. ${ }^{164}$ Slavs and Poles in eastern Germany had no rights as pagans, and therefore stood "outside the world order."165 Beginning with the reign of Otto I (936-973), the world order in eastern Germany was a Christian Empire, and the highest ideal of its rulers was to defend the Church against pagans. ${ }^{166}$ In this manner, the act of missionary work

\footnotetext{
${ }^{160}$ Erdmann, The Origin of the Idea of Crusade, 95.

161 Ibid., 96.

162 Tellenbach, The Church in Western Europe from the Tenth to the Early Twelfth Century, 9.

163 Ibid.

${ }^{164}$ Kelly DeVries, "God and Defeat in Medieval Warfare: Some Preliminary Thoughts," in The Circle of War in the Middle Ages: Essays on Medieval Military and Naval History, ed. Donald J. Kagay and L. J. Andrew Villalon (Woodbridge: Boydell Press, 1999), 97.

${ }^{165}$ Erdmann, The Origin of the Idea of Crusade, 100-101.

${ }^{166}$ Ibid., 102-103.
} 
and conversion became intertwined with state-supported warfare. ${ }^{167}$ Indeed, aggressive religious conversion also meant establishing the correct socio-political order. ${ }^{168}$

These conditions molded the tenth- and eleventh-century German bishop and his role, and the complex culture he existed in. On one hand, the bishop used Christian means to achieve political ends, and some may seem "saintly" due to the effects of hagiography. ${ }^{169}$ Yet, bishops were often pragmatic, and considered it their duty to protect the material and physical interests of their flocks. ${ }^{170}$ Due to their social status as nobility and grooming in the Ottonian Royal Chapel, the German bishop was often a courtier, who sought promotions, praise, and gifts from the emperor. ${ }^{171}$ Furthermore, as members of the nobility, they were also proud members of a martial class, ${ }^{172}$ even if church doctrine and biblical teachings sought to curtail violence and warfare. It appears as though the Church and the clergy faced systemic violence and were themselves split on how to react. In this scenario people acted according to their proclivities and made their own choices, with some clergy choosing a militant path for various reasons. Meanwhile, the church attempted to curtail violence in a time where central authority was weak, and even if it could not fully support violence and warfare, it still had to address pragmatic concerns, like self-defense.

\footnotetext{
${ }^{167}$ Ibid., 105-107.

${ }^{168}$ Ibid., 100-101.

${ }^{169}$ McKitterick, "The Church," 151-152.

170 Ibid.

${ }^{171}$ Jaeger, "The Courtier Bishop in Vitae from the Tenth to the Twelfth Century," 292, and Leyser, Germany and its Neighbours, 174.

${ }^{172}$ Arnold, "German Bishops and their Military Retinues in the Medieval Empire," 161.
} 


\section{Chapter 3}

\section{Source Analysis: Thietmar's Audience, Purpose, and Biography}

Thietmar of Merseburg (b. 975, r. 1009-18) was a bishop from a leading family in eastern Saxony, and his family, the Walbecks, were related to the Conradine royal line. ${ }^{173}$ Thietmar's chronicle of Ottonian Germany is considered one of the best primary sources for his time by medieval German specialists. Merseburg, the diocese he managed from 1009-1018, is as interesting and intricate as Thietmar was, due to its geography and political history. Geographically, Merseburg's location in north-eastern Germany meant that it was a key frontier territory, sharing a border with the Duchy of Poland to the east, the Liutizi people to the north, and the Duchy of Bohemia to the south. Frequently, these troubling neighbors, raiders, and rebels take center stage in the drama and conflict portrayed in Thietmar's writings. In addition, the diocese of Merseburg had been suppressed from 981-1004, an event which led to its destruction. ${ }^{174}$ Merseburg's destruction and subsequent reconstruction was one of Thietmar's most important reasons for writing his chronicle. ${ }^{175}$

Thietmar's complexities are best introduced through the labels scholars have used to characterize his personality and behavior. David Warner called him 'worldly,' specifically for his views on his responsibilities as an episcopal officer, ${ }^{176}$ and a 'militant Christian. ${ }^{177}$ Warner also borrowed a term used by Karl Leyser for Thietmar, and

\footnotetext{
${ }^{173}$ David Warner, “Thietmar of Merseburg on Rituals of Kingship,” Viator 26 (1995): 64.

${ }^{174}$ Warner, Ottonian Germany, 17.

${ }^{175}$ Warner, "Thietmar of Merseburg on Rituals of Kingship," 66.

${ }^{176}$ Warner, Ottonian Germany, 34.

${ }^{177}$ Ibid., 41.
} 
referred to him as a 'frontier bishop, ${ }^{178}$ a term meant to reflect Thietmar's concerns as a clergyman positioned on a militarily active border with recently converted Christians. Additionally, he should be thought of as an 'imperial bishop,' due to his position as an advisor to King Henry II (r. 1002-1024) and his participation in local and regional politics. ${ }^{179}$ All of these terms possess an element of ecclesiasticism; Thietmar was no doubt a bishop and his writing often reflects a connection with Christian morals and beliefs one might expect from a bishop. Yet each label contains a second important ingredient, evoking a secular, practical framework that Thietmar seems to have embraced as part of his duties. Phrases like 'worldly bishop,' 'militant bishop,' 'imperial bishop,' and 'frontier bishop' all possess additional qualifiers that must be considered alongside Thietmar's ecclesiastical position. He was not simply a member of the clergy preaching to his congregation and managing his diocese; he was also a vassalic lord responsible for defending his territory and providing military support for his ruler and the kingdom.

Since Merseburg was located in a strategically important position along the northeastern frontier, Thietmar was required to defend his borders against neaby incursions from Slavic raiders and rebels. ${ }^{180}$ This job put him in a position to command military forces, and his location provided a convenient (and necessary) staging area for King Henry II's campaigns into Poland and Bohemia. Additionally, Merseburg was the site of Henry II's favored royal residence, so Thietmar spent much of his career around the Ottonians. ${ }^{181}$ As a confidant of King Henry II and his wife Queen Cunegunda, Thietmar

\footnotetext{
${ }^{178}$ Warner, Ottonian Germany, 60.

179 Ibid., 16.

${ }^{180}$ Ibid., 52.

${ }^{181}$ Warner, "Thietmar of Merseburg on Rituals of Kingship," 64.
} 
"participated in numerous planning sessions,"182 which meant he was trusted and knowledgeable.

If it seems that Thietmar was the perfect person to manage such a tumultuous region and advise on military matters, it is because he was prepared in his youth for his future leadership role as a bishop and territorial lord. In early childhood he was sent to study under his aunt Emnilde at Quedlinburg until he was twelve. ${ }^{183}$ Later, Thietmar's father sent him to the monastery of Berge for more training, then he was placed into the cathedral chapter in Magdeburg, where he was trained in the classics. ${ }^{184}$ The chapter at Magdeburg was known for its quality, having had two masters regarded for their intellectual prowess. ${ }^{185}$ This educational program was organized with the goal of improving the intellect and the character, therefore it would have prepared young men for service with the king. ${ }^{186}$ His time in Magdeburg may have been the source for Thietmar's ideas of 'courtliness,' which likely played a significant role in his later admiration for 'courtier bishops.' 187

As the third-born among six children, Thietmar was keenly aware of his family's position and socio-political status. ${ }^{188}$ He was a member of a family known for its military commanders, ${ }^{189}$ and related through his maternal grandfather to the Conradine line, a significant family who would supply a future emperor-Conrad II (1024-1039)-from the

\footnotetext{
182 Bachrach, "The Military Organization of Ottonian Germany,” 1067.

${ }^{183}$ Warner, Ottonian Germany, 45.

${ }^{184}$ Ibid., 52-53.

185 Ibid., 53.

186 Ibid., 54.

${ }^{187}$ Ibid., 54. For background on the phenomena of courtier bishops, see Jaeger, "The Courtier Bishop in Vitae from the Tenth to the Twelfth Century."

188 Ibid., 40.

${ }^{189}$ Bachrach, "The Military Organization of Ottonian Germany," 1067.
} 
Rhineland and Swabia. ${ }^{190}$ Thietmar's brothers had achieved prominent posts, and he likely expected to achieve something similar. His eldest brother, Henry, received their father's countship, while the second son, Frederick, eventually became burgrave of Magdeburg. ${ }^{191}$ Furthermore, many of his male family members served as military commanders. ${ }^{192}$ Thietmar's two younger brothers also received high clerical positions. His brother Siegfried was appointed bishop of Münster (1009-22), and his youngest brother, Brun, became bishop of Verden (1034-49).

Thietmar was a complicated individual who expressed some uncommon viewpoints for his era; however, others were more typical. While Thietmar turned to the supernatural when he needed to achieve "one of his personal agendas," $" 193$ he maintained his sense of worldliness. David Warner provided an example of Thietmar leaning towards the supernatural when it suit him. After Otto I had denied the appointment of a clergyman to the archbishopric at Cologne, despite the fact that the candidate had been fairly elected, Thietmar wrote that an angel appeared and threatened Otto with death. ${ }^{194}$ Like many in his time, divine intervention and judgment were part of life, and signs of God's displeasure (or favor) are sprinkled throughout his text. Yet Thietmar preserved his pragmatism, and sometimes these positions created tensions that are evident while reading. Another common feature of Thietmar's mindset was his rigid views on the social hierarchy. He was sensitive to distinctions and categories that defined people, to the point

\footnotetext{
${ }^{190}$ Warner, Ottonian Germany, 50.

191 Ibid., 52.

${ }^{192}$ Bachrach, "The Military Organization of Ottonian Germany," 1067.

${ }_{193}$ Warner, Ottonian Germany, 39.

${ }^{194}$ Ibid.
} 
that he had a low opinion of peasants. ${ }^{195}$ Upward social movement was uncommon in his age, and when it occurred, it attracted attention and concern. ${ }^{196}$ By contrast, Thietmar's favorable views on women were unusual for his time, and may be attributed to his time studying under his aunt Emnilde at Quedlinburg. ${ }^{197}$ Women's participation in politics did not seem to bother Thietmar, to the point where he expressed admiration for many, including Abbess Mathilda, Empress Theophanu, and Empress Cunegunde. ${ }^{198}$

Thietmar's positions-socially, politically and geographically-are what gave him such interesting material to record in his Chronicon, a lengthy and informative historical work, influenced by the Quedlinburg Annals. ${ }^{199}$ His complex personality, behavior, and attitudes provide rich material for scholars and readers of early eleventh-century episcopal, family, and political history. Often he presented character sketches of bishops and clergy, listed their activities, and reflected upon their ethics. Deeds of kings, emperors, and counts populate the Chronicon's pages, alongside the many raids, rebellions, feuds, and military campaigns that characterize Thietmar's experience. Understanding Thietmar's social, political, and cultural context need to inform one's reading of his Chronicon.

\footnotetext{
195 Warner, Ottonian Germany, 40.

196 Ibid.

197 Ibid., 48.

${ }^{198}$ Ibid., 48-49.

199 Ibid., 62.
} 


\section{Thietmar's Chronicon: Audience, Purpose, and Place in the Source Base}

The long tenth century (c. 890-1030) is an age known among historians for a paucity of primary sources. ${ }^{200}$ During this time, the steady stream of Carolingian-era charters, capitularies, canon law, and narratives slowed to a trickle. ${ }^{201}$ Much of this trend is attributed to weaker socio-political institutions, and perhaps a slight decline in literacy. ${ }^{202}$ For historians, this scarcity has made determining a chronology of events during this era more difficult. ${ }^{203}$ However, while the source base for this period is more thin, the long tenth century contains several excellent annals and chronicles-written by "great historians"-and enough hagiographies to warrant calling it a "golden age" of hagiographical output. ${ }^{204}$ Thietmar of Merseburg's Chronicon sits firmly in this set of sources, among contemporary works by Widukind of Corvey, Adalbert of Magdeburg, Flodoard and Richer in Reims, Dudo of Saint-Quentin in Normandy, Adhémar of Chabannes, Radulf Glaber in Central France, and the anonymous authors of the Quedlinburg Annals, to name a few. In their works historians and writers, according to Timothy Reuter, "tend to express the more or less standard array of teleological and propagandistic causae." ${ }^{205}$ While Reuter remarked that these sources are regarded as thoroughly mined, ${ }^{206}$ and their content completely covered, ${ }^{207}$ Reuter, Warner, and others

\footnotetext{
${ }^{200}$ Reuter, "Introduction: Reading the Tenth Century," 1.

${ }^{201}$ Ibid., 5-6.

202 Ibid., 2.

203 Ibid., 1-2.

204 Ibid., 3.

${ }^{205}$ David A. Warner, "Reading Ottonian History: The Sonderweg and Other Myths," in Challenging the Boundaries of Medieval History: The Legacy of Timothy Reuter, eds. Patricia Skinner and Henry MayrHarting (Turnhout, Belgium: Brepols, 2009): 103.

${ }^{206}$ Reuter, Germany in the Early Middle Ages, 2.

${ }^{207}$ Reuter, "Introduction: Reading the Tenth Century," 13-14.
} 
have called for the period to be examined again on its own terms, leaving aside modern anachronisms, judgments, and viewpoints. ${ }^{208}$

Thietmar of Merseburg is one of the historians who provides us with much of our understanding of the reigns of Otto III (973-983) and Henry II (1002-1024). ${ }^{209}$ In fact, due to Thietmar's talent as a historian, the Chronicon is recognized as the best source for Henry II's reign. ${ }^{210}$ David Warner appreciated the Chronicon's “attention to detail, breadth of interests ... and its author's well-informed perspective." ${ }^{211}$ Military historian David Bachrach praised Thietmar for his exceptional military knowledge. ${ }^{212}$ The Chronicon's memorializing tone makes it unique for its era, making it "best compared to the great aristocratic memoirs of the seventeenth- and eighteenth-centuries, ${ }^{, 213}$ and Reuter characterized the work as "the memoirs of a Saxon aristocrat, a source of value far beyond the mere information it provides about the flow of political events." ${ }^{214}$ Scholars have also commented upon Thietmar's honesty, even when discussing his heroes, those royal and imperial subjects who often take center stage in his Chronicon. ${ }^{215}$ Thietmar had a sense of his time and place, specifically in terms of the grandeur of the events surrounding him. ${ }^{216}$ Many of the events he recorded were ones he witnessed himself, or

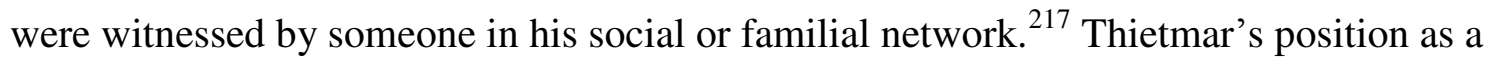

\footnotetext{
${ }^{208}$ Warner, "Reading Ottonian History," 101-102 and Reuter, "Introduction: Reading the Tenth Century," 14.

${ }^{209}$ Warner, "Reading Ottonian History," 101-102.

${ }^{210}$ Bachrach, "The Military Organization of Ottonian Germany," 1066.

${ }^{211}$ Warner, "Thietmar of Merseburg on Rituals of Kingship," 64.

212 Bachrach, "The Military Organization of Ottonian Germany," 1067.

${ }^{213}$ Timothy Reuter, "Thietmar, Bishop of Merseburg," in Encyclopedia of Historians and Historical Writing, vol. 2, ed. Kelly Boyd (Chicago: Fitzroy Dearborn, 1999), 1183-1184.

${ }^{214}$ Reuter, Germany in the Early Middle Ages, 3.

${ }^{215}$ Robert E. Lerner, "Thietmar von Merseburg," in Dictionary of the Middle Ages, vol. 12, ed. Joseph R. Strayer (New York: Scribner, 1982), 27-28.

${ }^{216}$ Warner, Ottonian Germany, 16-17.

${ }^{217}$ Ibid., 49.
} 
bishop, his connections in a leading Saxon aristocratic family, and the fact that he wrote about key political events he often witnessed, are what makes his Chronicon so useful and interesting. ${ }^{218}$

Thietmar took advantage of his access to quality source documents for his Chronicon, and writing this work spanned several years. Indeed, in his introduction to the Latin edition, Robert Holtzmann called the Chronicon Thietmar's magnum opus. ${ }^{219}$ Thietmar began writing his Chronicon in 1012, four years after Henry made him bishop at Merseburg, and completed the first three books by the Summer of $1013 .^{220}$ Thietmar wrote steadily from 1013 forward, until by Book Seven, he apparently wrote about events not long after they happened; and in Book Eight, written in 1018, he wrote about events around the time of their occurrence. ${ }^{221}$ He worked on the Chronicon until his death, even dictating content to a scribe as "he lay ill and dying.,"222

Thietmar's writing process for the Chronicon involved utilizing a combination of existing written sources, oral testimony, and his own experiences. The first three books, which span the period before his lifetime, were compiled from a contemporary history, known as the Quedlinburg Annals, ${ }^{223}$ and from Widukind of Corvey's History of the Saxons, to which he added "other traditions and anecdotes." 224 In addition to the Annals, Thietmar leveraged other sources, like Gerhard's biography of Bishop Ulrich of Augsburg, Ruotger's life of Archbishop Brun of Cologne, perhaps a biography of Queen

\footnotetext{
${ }^{218}$ Warner, Ottonian Germany, 49.

${ }^{219}$ Robert Holtzmann, ed., Die Chronik des Bischofs Thietmar von Merseburg und ihre Korveier Überarbeitung, Monumenta Germaniae Historica, Scriptores Rerum Germanicarum, Nova Series, 9 (Berlin: Weidmannsche Buchhandlung, 1935), xxviii: "Sein Hauptwerk aber bleibt die Chronik."

${ }^{220}$ Warner, "Thietmar of Merseburg on Rituals of Kingship," 64, and Warner, Ottonian Germany, 61.

${ }^{221}$ Warner, Ottonian Germany, 61.

${ }^{222}$ Leyser and Reuter, Communication and Power in Medieval Europe, 28.

${ }^{223}$ Warner, Ottonian Germany, 61.

${ }^{224}$ Reuter, Germany in the Early Middle Ages, 3.
} 
Mathilda, and a variety of documents from Merseburg, Magdeburg, and Walbeck. ${ }^{225}$

Thietmar combined these with extensive oral accounts from friends, family, and acquaintances, and in later books, he wrote from his own experiences. ${ }^{226}$

Only two manuscripts of Thietmar's Chronicon survive; both are copies and located in Germany. ${ }^{227}$ Thietmar's contemporaries apparently appreciated the Chronicon because it was used just a few years after his death by Bishop Adalbold of Utrecht for a biography on Henry II. ${ }^{228}$ The Chronicon was also used as a source for other chronicles written in the twelfth century about Magdeburg and its surroundings. ${ }^{229}$ Interestingly, scholars do not consider Thietmar's Chronicon a "pure text" because it was written using a staff of at least eight scribes and includes edits and additions by Thietmar, and the original version was obviously altered by monks at Corvey in the twelfth century. ${ }^{230}$ These changes and edits can be compared by examining the two remaining manuscripts, and were incorporated in different ways in both the 1935 German edition of the Latin by Robert Holtzmann, and in David Warner's 2001 English translation. ${ }^{231}$ This knowledge has produced a debate surrounding the relationship between the altered version and Thietmar's original. ${ }^{232}$

The organization of the Chronicon fits Thietmar's expressed purpose of glorifying kings. ${ }^{233}$ It contains eight books, and the first book opens with a brief prologue-in the form of a poem-stating Thietmar's dedication and intentions for writing, before

\footnotetext{
${ }^{225}$ Warner, Ottonian Germany, 62.

${ }^{226}$ Ibid., 49, 61-62.

${ }^{227}$ Ibid., 62 .

228 Ibid.

229 Ibid

${ }^{230}$ Warner, "Reading Ottonian History," 103-104.

${ }^{231}$ Warner, Ottonian Germany, 62-64.

${ }^{232}$ Warner, "Reading Ottonian History," 103-104.

${ }^{233}$ Reuter, "Thietmar, bishop of Merseburg," 1183-1184.
} 
launching into Book One proper, and the reign of Henry I. Books Two and Three also open with poems, glorifying emperors Otto I and II respectively, and each book covers a substantial amount of time-several decades, in fact. Book Four opens in 984, just after Emperor Otto II's death, and is one of two books that does not feature a poem. This book ends at the end of Otto III's reign in 1002, and marks a transition in the Chronicon, where Thietmar's narrative becomes more granular. This is demonstrated throughout the remaining three books, because each narrate a smaller amount of time during the reign of Henry II (1002-1024). Book Five begins with a poem venerating Henry II's election, and covers the years 1002-03. Book Six spans events during 1004-1013, Book Seven covers 1014-1017, and both begin with poems. Book Eight is the final book, lacks a poem, and ends in 1018, upon Thietmar's death.

In the Prologue, where Thietmar dedicated the Chronicon to his younger brother, Siegfried, Thietmar laid out his goals for writing. One was to record and preserve Merseburg, his diocese, which had been suppressed between 981 and 1004, and had recently been reinstated. ${ }^{234}$ Secondly, Thietmar wrote to record the life and habits of the kings of Saxony, who stood out like a cedar tree and projected dread, yet were pious. ${ }^{235}$ This is a biblical reference alluding to the Assyrian kingdom, which established itself through strength, yet allowed its arrogance to bring about its downfall. ${ }^{236}$ Thietmar also wrote that reading his Chronicon required constant use and fondness, and offered his

\footnotetext{
${ }^{234}$ Warner, Ottonian Germany, 17.

${ }^{235}$ Holtzmann, ed., Die Chronik des Bischofs Thietmar von Merseburg und ihre Korveier Überarbeitung, 3 : "Hec non ornatu splendent dictaminis ullo/sed tantum plano percurrunt ordine campo/Saxonie regum vitam moresque piorum/Quorum temporibus regnum velut ardua cedrus/Enituit nostrum longe lateque timendum.” (English) Warner, Ottonian Germany, 66. Ezekiel 31:3 ISV.

${ }^{236}$ Ezekiel 31:3 ISV.
} 
writings as a prescription for "gloomy thoughts." ${ }^{, 237}$ With these comments Thietmar wrote for posterity, and a hope that his text would be used for moral instruction, especially for those ecclesiastics who would succeed him in Merseburg. David Warner emphasized this intention, namely that Thietmar wanted to highlight the importance of royal favor on the abilities of his successors to rule Merseburg successfully, and hoped his writing would be used to demonstrate this reality as he saw it. ${ }^{238}$ Finally, Thietmar described another hope for his readers, that they should aspire to spirituality over materialism. Thietmar wrote that his chronicles should be "placed in front of games and other vain things: may you [the reader] be found praising the just and praying for sinners., 239

Another underlying motive for Thietmar's Chronicon may have been a desire to promote his ecclesiastical position and the Walbeck name in the region. Thietmar possessed knowledge of his family's history for at least three generations, ${ }^{240}$ and his ancestors' deeds often populate the Chronicon's pages. As for his motive to venerate his familial name, one of Thietmar's ancestors, Liuthar, had been in a group of conspirators who made an assassination attempt against King Otto I in $941 .{ }^{241}$ While restitution had been made, and Thietmar's family had regained royal favor, ${ }^{242}$ this history may still have weighed upon Thietmar. Walbeck family dynamics perhaps also formed part of Thietmar's motives. As a middle-child in a prominent family, it is possible that Thietmar felt a need to establish himself as a successful territorial lord, and ensure that his brothers

\footnotetext{
${ }^{237}$ Holtzmann, ed., Die Chronik des Bischofs Thietmar, 5: "Cronica Thietmari se poscunt, lector, amari/Usibus assiduis excludunt tristia mentis." (English) Warner, Ottonian Germany, 67.

${ }^{238}$ Warner, Ottonian Germany, 17.

${ }^{239}$ Holtzmann, ed., Die Chronik des Bischofs Thietmar, 5: "Ludis et variis eadem preponito vanis:/Sis iustos laudans, pro peccatoribus orans." (English) Warner, Ottonian Germany, 67.

${ }^{240}$ Warner, Ottonian Germany, 49.

${ }^{241}$ Ibid., 50.

${ }^{242}$ Warner, Ottonian Germany, 50.
} 
and extended family recognized that he was adding to the Walbeck legacy, not diminishing it. Having been raised among counts and bishops, perhaps Thietmar felt competitive pressure.

The amount of care and attention Thietmar placed upon his work demonstrates that it must have meant a great deal to him. The poetic introductions, along with his wellcrafted prologue, add a level of intimacy and humanity that help create the literary tone reflected throughout the Chronicon, which is a mixture of event-driven political narrative and personal commentary. He intended it to be read by family, friends, and other clergy, and judging by the fact that his writings were used for other chronicles shortly after his death, ${ }^{243}$ Thietmar's wish was fulfilled.

${ }^{243}$ Warner, "Reading Ottonian History: The Sonderweg and Other Myths," 103-104. 


\section{Chapter 4}

\section{Investigation: Thietmar's Accounts of Clerical Violence}

Since war was society's "primary and perennial occupation" 244 during his time, it should not be surprising that Thietmar of Merseburg's Chronicon contains many violent scenes. Thietmar wrote frequently about Christians fighting other Christians in acts of rebellion, during feuds, or simply when plundering or pillaging lands for personal gain or vengeance. Violence and warfare also occurred between Christians and other groups, whom Thietmar identified by their geographic location, such as Hungarians, Danes, Bohemians, and Slavs. In other cases, Thietmar identified enemy combatants as pirates, heathens, or Saracens. Many of these cases involved a member of the nobility, and frequently the emperor or king. However, many cases also involved a member of the clergy, with bishops and archbishops often playing the starring role.

Among the cases of violence and warfare mentioned by Thietmar, there are sixtyfive separate incidents that involved a member of the clergy in some capacity. David Warner's English edition contains 319 pages of the Chronicon, not counting extraneous content, such as the Introduction. This means that an instance of violence or warfare involving a member of the clergy occurs in the Chronicon about once every five pages. Indeed, clerical violence or warfare occured regularly, and it occupied Thietmar's existence.

${ }^{244}$ Leyser, "Early Medieval Warfare," 29. 


\begin{tabular}{|c|c|c|c|}
\hline Violence Type & vs. Christians & vs. Others & Total \\
\hline Feuding & 9 & 0 & 9 \\
\hline Plundering & 6 & 2 & 8 \\
\hline Preaching & 0 & 3 & 3 \\
\hline Rebellion & 30 & 1 & 31 \\
\hline Warfare & 0 & 14 & 14 \\
\hline Total & 45 & 20 & 65 \\
\hline
\end{tabular}

Table 1.1 displays the breakdown of these occurrences, by type of violence and parties involved. The objective of this dataset is to provide some quantitative context for clerical violence recorded by Thietmar, and is not intended to provide a complete statistical analysis. Tabulating this data required some analytical and categorical subjectivity because Thietmar did not always provide sufficient detail to understand the circumstances. The labels used to categorize and define the participants involved in each violent act were defined by Thietmar, using his own terminology when possible. For example, if Thietmar wrote the word feud, then that term was used when recording the incident. However, when Thietmar's terminology was less definitive, or when he mixed labels, then a term was applied in an attempt to determine the context in which the violence occurred. Furthermore, our modern categories for this violence would not necessarily match Thietmar's viewpoints. For example, Thietmar may characterize a battle against a subjected group-like the Slavs-as a "rebellion" or a "revolt," even though we may also define that as an act of warfare against a foreign enemy. For the purposes of this data set, violence involving a foreign group was considered "warfare" and not 
"rebellion," even if Thietmar defined it as such. However, those determinations were balanced with the need to preserve and capture Thietmar's own terminology and viewpoints, while attempting to maintain consistency from case to case.

These data do show, however, that members of the clergy participated in all types of violence and warfare, and their participation in violence occurred in a variety of circumstances. They fought in political struggles against foreigners and countrymen, attempted to convert others to Christianity, and contributed to feuds and rebellions. The roles these clergy performed in acts of violence also varied. Sometimes they led armies against foreign threats or to squash rebels. In other instances, bishops were charged with defending a city or territory by their king or emperor. For example, Archbishop Heribert of Cologne (999-1021) led soldiers to aid Emperor Otto III after a rebellion in Rome, an act in which the emperor rejoiced. ${ }^{245}$ In another case two bishops, Giselher and Hildeward, were among the key figures who gathered an armed force to attack an army of Slavs, who had laid waste to several towns and villages near the Tonger River. ${ }^{246}$ While often portrayed as active participants in violence, bishops and clergy were sometimes victims, but not always innocent ones. Among several instances of murdered bishops and clergy reported by Thietmar, one notable incident involved John of Calabria, who was made pope during Crescenzo's rebellious seizure of Rome during the legitimate

\footnotetext{
${ }^{245}$ Holtzmann, ed., Die Chronik des Bischofs Thietmar, 186: "Deinc nuntio suimet omnes cesar sibi familiares convenire illuc rogat et precipit, demandas singulis quibusque, si umquam de honore sui vel incolumitate curarent, ad ulciscendum eum ac amplius tuendem armato ad se milite properarent." "Conveniente tum cum Heriberto, sanctae Agripinae archiepiscopo, plurima fidelium turba, inperator laetatur...” (English) Warner, Ottonian Germany, 186.

${ }^{246}$ Ibid., 120-122: "Conveniunt episcopi Gisillerus et Hilliwardus cum marchione Thiedrico caeterisque comitibus, Ricdago, Hodone et Binizone, Fritherico, Dudone ac patre meo Sigifrido aliisque compluribus; qui ut dies sabbati primo illuxit, missam omnes audiunt, corpus animamque caelesti sacramento muniunt hostesque obvios fiducialiter inrumpentes, paucis in unum collem effugientibus, prosternunt." (English) Warner, Ottonian Germany, 142-143.
} 
Pope Gregory V's (r. 996-999) absence. After fleeing Rome in 998, John the anti-pope was captured by Emperor Otto III's (r. 983-1002) forces and punished: "by faithful servants of Christ and caesar, he lost his tongue, eyes, and also his nostrils."247 Finally, bishops are reported by Thietmar performing mass before battles, or in camp with their soldiers. ${ }^{248}$ In one case, Bishop Ramward of Minden (r. 996-1002) inspired his soldiers to victory while leading them and carrying his cross in a battle against Slavs. ${ }^{249}$ In another example, when local bishops and nobles gathered an army to counter the Slav uprising in 983, the clergy led the army in mass before the battle, ${ }^{250}$ which earned them divine strength. ${ }^{251}$ The role of warrior or soldier was another role performed by clergy, although that was an uncommon occurrence according to Thietmar. When a member of the clergy did fight, Thietmar generally characterized him as honorable or glorious.

\footnotetext{
${ }^{247}$ Holtzmann, ed., Die Chronik des Bischofs Thietmar, 167: "Iohannes autem supplantator hiis appropinquantibus fugit; sed postea a fidelibus Christi et cesaris captus, linguam cum oculis ac naribus amisit." (English) Warner, Ottonian Germany, 173.

${ }^{248}$ A topic covered thoroughly in David Bachrach, Religion and the Conduct of War.

${ }^{249}$ Holtzmann, ed., Die Chronik des Bischofs Thietmar, 167: “...nostras regiones invisit et accepta Sclavorum rebellione Stoderaniam... In illo certamine Ramwardus Mindensis episcopus fuit, qui socios, arrepta in manibus cruce sua, sequentibus signiferis precessit et ad hec facienda potenter consolidavit." (English) Warner, Ottonian Germany, 172.

${ }^{250}$ Ibid., 120-122: "Desolatis tunc omnibus preda et incendio urbibus ac villis usque ad aquam, quae Tongera vocatur, convenerunt e Sclavis peditum ac equitum plus quam XXX legiones, quae sine aliqua lesione residua quaeque suorum auxilio deorum tunc devastare non dubitarent, tubicinis precedentibus. Conveniunt episcopi Gisillerus et Hilliwardus cum marchione Thiedrico caeterisque comitibus, Ricdago, Hodone et Binizone, Fritherico, Dudone ac patre meo Sigifrido aliisque compluribus; qui ut dies sabbati primo illuxit, missam omnes audiunt, corpus animamque caelesti sacramento muniunt hostesque obvios fiducialiter inrumpentes, paucis in unum collem effugientibus, prosternunt." (English) Warner, Ottonian Germany, 142-143.

${ }^{251}$ Ibid.: "Conveniunt episcopi Gisillerus et Hilliwardus cum marchione Thiedrico caeterisque comitibus, Ricdago, Hodone et Binizone, Fritherico, Dudone ac patre meo Sigifrido aliisque compluribus; qui ut dies sabbati primo illuxit, missam omnes audiunt, corpus animamque caelesti sacramento muniunt hostesque obvios fiducialiter inrumpentes, paucis in unum collem effugientibus, prosternunt." (English) Warner, Ottonian Germany, 142-143.
} 


\section{Thietmar on Violent Clergy and Rebellions}

The most common type of clerical violence reported by Thietmar was rebellion, comprising $48 \%$ of all cases of clerical violence. ${ }^{252}$ Most often these instances were defined by Thietmar as political disputes between noble factions, or ones directed at the emperor. ${ }^{253}$ Clergy participated on both sides of rebellions, ${ }^{254}$ sometimes as one of the instigators, such as Archbishop Giselher of Magdeburg, who had supported King Henry II's political rival, Herman. ${ }^{255}$ In other instances, such as in the uprising in Verona during King Henry II's election in 1002, one archbishop demonstrated his support for the king by leading an army to reinforce him; meanwhile another bishop defended his city from an attack by the rebels. ${ }^{256}$ While Thietmar reported the above examples without commentary that revealed his feelings or thoughts on the actions of these militant bishops, he did state them clearly in another passage.

Early in his Chronicon, Thietmar lamented the act of rebellion and equated it to a suicidal act by unfaithful soldiers: "Our predecessors, themselves always having the best

\footnotetext{
${ }^{252}$ See Table 1.1 in this document.

${ }^{253}$ Reuter provides an excellent narrative on the regular rebellions against Ottonian rulers by their friends and family in Germany in the Early Middle Ages, 183-220.

${ }^{254}$ See Dominik Waßenhoven, "Swaying Bishops and the Succession of Kings," in Patterns of Episcopal Power: Bishops in Tenth and Eleventh Century Western Europe = Strukturen Bischöflicher

Herrschaftsgewalt im westlichen Europa des 10. und 11. Jahrhunderts, ed. Ludger Körntgen and Dominik Waßenhoven (Berlin: De Gruyter, 2011), 88-109, which examines the involvement of bishops in succession disputes for Otto III (983) and Conrad II (1024).

${ }^{255}$ Holtzmann, ed., Die Chronik des Bischofs Thietmar, 265: "Hunc archiepiscopum Gislerum rex primo propter Heremannum ducem, quem idem sibi in regno summopere conabatur preponere, odivit..." (English) Warner, Ottonian Germany, 231.

256 Ibid., 249-251: "Hunc ex parte regis venientem archiepiscopum Ravenne Frithericum cum marchione Thiedolfo ceterisque regis fidelibus ei ad auxilium occurrentem Hartwigus inmedio positus linsceisque oculis omnia perlustrans cum comperiret, ad interrumpendos eos Veronam cum magna multitudine venit clusasque ab episcopo eiusdem civitates huc usque munitas expugnando cepit." (English) Warner, Ottonian Germany, 222.
} 
faithful soldiers, were raging with arms in foreign nations, not in their own vital areas." 257 With this statement, Thietmar displayed a sense of nostalgia for his ancestors and their faithful soldiers, and expressed regret with internecine conflict in the same breath. While Thietmar did not specifically use language here that would indicate he approved of wars in foreign nations or against non-Christian foes, nevertheless he equated its oppositeviolence against other Christians in the form of rebellions-as a self-destructive act, and therefore found it contemptible. However, Thietmar's disdain for rebellion did not mean that everyone participating in this type of violence automatically earned his disfavor, including bishops and clergy. There were opportunities even during rebellions for abbots, bishops, and other clergy to earn his praise.

Bishop Henry of Würzburg and Abbot Erkanbald of Fulda, for example, were sent by King Henry to burn and destroy the burg Schweinfurt during a rebellion in $1003 .{ }^{258}$ But instead of burning and destroying the burg, they only broke the walls of the city and buildings, pulling them to the ground. ${ }^{259}$ According to Thietmar, these two ecclesiastical lords "postponed their secular fears on account of their love for Christ."260 While Thietmar did not explicitly praise these two for their change of heart, accrediting their actions to their "love of Christ" seems to elevate their motivations to disobey orders from their sovereign to something a Christian would find admirable. Thietmar's explanation for why these two clergy ostensibly failed in their mission helps demonstrate Thietmar's

\footnotetext{
${ }^{257}$ Holtzmann, ed., Die Chronik des Bischofs Thietmar, 335: "Nostri predecessores suis prelatis semper fideles optimi milites in extraneis nacionibus non in suis visceribus armis seviebant." (English) Warner, Ottonian Germany, 271.

${ }^{258}$ Ibid., 264: "Misit tunc Heinricum, Wirciburgiensis [ecclesiae] episcopum, et Erkanbaldum, Fuldensis coenobii abbatem, ut Suinvordi castellum incenderent atque diruerent.” (English) Warner, Ottonian Germany, 230.

${ }^{259}$ Ibid.: “...murosque urbis ac aedifitia solotenus frangentes.” (English) Warner, Ottonian Germany, 231.

${ }^{260}$ Ibid.: "Unde seniores prefati ob christi amorem seculares postponendo timores decretam mutabant sententiam..." (English) Warner, Ottonian Germany, 231.
} 
attitude towards their actions. When Bishop Henry of Würzburg and Abbot Erkanbald of Fulda arrived at Schweinfurt, they were greeted by Count Henry's admirable mother, Eila. Once she learned of their intentions, "she was disturbed and hastened to the church with a rapid run," she testified that "she would sooner undergo being burned by fire" than see it destroyed. ${ }^{261}$ One can imagine how that interaction must have unfolded, and how an abbot and a bishop must have been moved to defy their orders. Indeed, according to Thietmar, the men were "soothing the sad matron," and promising "to rebuild the whole thing from their share.”262 Thietmar painted a sentimental scene between these two clergy, sent under orders to destroy a rebellious stronghold, but who heard the pleas from a distraught noble matron and heeded their Christian ethics to perform a lighter form of justice. This example demonstrates that bishops had the ability to amend their instructions in favor of less violent outcomes. While Thietmar may not have offered outright praise for their actions, he also did not condemn them, nor did he chastise them for being unfaithful to King Henry.

Thietmar reported that members of the clergy played other key military roles on Henry's behalf. First, bishops were summoned to support him militarily out of their duty to him, and secondly, a bishop defended his city against an attack by the rebels. In 1002, the king of Italy, Arduin I (1002-1015), led a revolt against King Henry II shortly after

\footnotetext{
${ }^{261}$ Holtzmann, ed., Die Chronik des Bischofs Thietmar, 264: "Quos adventantes Heinrici comitis inclita mater Eila nomine, ut talibus decebat personis, suscipiens et salutans, ut precepta intellexit regalia, perturbatur concitoque cursu ad aeclesiam properans, ibidem ignis concremationem prius sustinere, quam hac comburente viva vellet exire, testatur." (English) Warner, Ottonian Germany, 230.

${ }^{262}$ Ibid.: "Unde seniores prefati ob christi amorem seculares postponendo timores decretam mutabant sententiam; murosque urbis ac aedifitia solotenus frangentes, tristem matronam his mulcebant promissis, si quando cum gratia regis id fieri potuisset, hoc totum ex sua parte se renovaturos." (English) Warner, Ottonian Germany, 230.
} 
his election. Thietmar neither praised nor condemned these clergy for their participation in these military affairs, but reported their actions rather straightforwardly:

Out of duty for the king come Archbishop Frederick of Ravenna together with Margrave Thedald and the rest of the king's faithful to aid him. When Hartwig [Arduin], positioned in the middle and surveying everything with eagle eyes, discovered this, he came to Verona with a great host to intercept them, and seized the passes from the bishop of the same city, storming the defenses here and there. $^{263}$

In contrast to the actions by Bishop Henry of Würzburg and Abbot Erkanbald of Fulda, who were noted for following their love of Christ, these clergy who dutifully supported King Henry or defended their city did not earn similar attention. However, Thietmar wrote that it was their obligation to act, and that the clergy performed this duty. Thietmar commonly reported clerical violence and warfare in this manner, without providing a moral commentary on their actions. His style of reporting this account implies that these clerical actions in the military sphere were appropriate and expected.

\section{Thietmar On Missionary/Preaching Violence}

Thietmar recorded three cases in which conversion or missionary activities in border territories resulted in violence against clergy. In the only case that did not result in death or martyrdom, Adelbert of Trier was expelled from Russia by pagans after having

\footnotetext{
${ }^{263}$ Holtzmann, ed., Die Chronik des Bischofs Thietmar, 249-251: "Hunc ex parte regis venientem archiepiscopum Ravenne Frithericum cum marchione Thiedolfo ceterisque regis fidelibus ei ad auxilium occurrentem Hartwigus inmedio positus linsceisque oculis omnia perlustrans cum comperiret, ad interrumpendos eos Veronam cum magna multitudine venit clusasque ab episcopo eiusdem civitatis huc usque munitas expugnando cepit." (English) Warner, Ottonian Germany, 222. Warner's translation replaces Hartwigus with Arduin.
} 
first been made bishop of the region. ${ }^{264}$ The other bishops were not so lucky, because they were murdered and beheaded as a result of their missionary work. As a result, Thietmar praised them both as martyrs. One martyr, the archbishop Adalbert of Magdeburg, was a worthy Christian who was unable, despite his education and humility, ${ }^{265}$ to "move those entrusted to him from their long-standing depravity, by the warnings of God's teachings." ${ }^{, 266}$ After some time passed, during which Adalbert conducted himself as a good Christian, he returned to Prussia in order to convert them through his preaching. ${ }^{267}$ Apparently Adalbert's preaching was unsuccessful, because next Thietmar wrote he had been "stabbed by a spear, on the ninth day before the Kalends of May, he alone secured his long desired martyrdom, and without any groan. ${ }^{, 268}$ It is unclear if Adalbert was murdered, or if his martyrdom occurred during a fracas. The second martyrdom earned through preaching also occurred near Prussia, where a similarly celebrated member of the clergy, bishop Brun of Merseburg, endeavored to civilize the inhabitants. ${ }^{269}$ Without providing more detail regarding the situation-why it occurred, who exactly was involved, what triggered it-Thietmar reported

${ }^{264}$ Holtzmann, ed., Die Chronik des Bischofs Thietmar, 65: "Sed visa quadam epistola, que clanculum sibi deferebatur, omisit, Athelbertum vero Treverensem, professione monachum, sed Ruscie prius ordinatum presulem et a gentilibus hinc expulsum..” (English) Warner, Ottonian Germany, 108.

${ }^{265}$ Ibid., 165: “...superius memorato litteris instructus... eiusque licencia sub districta Bonifacii abbatis regula humiliter multo tempore conversatus, bono deguit exemplo.” (English) Warner, Ottonian Germany, 171.

${ }^{266}$ Ibid.: “...cum sibi commissos ab antique pravitatis errore monitis divini precepti amovere nequivisset, omnes excommunicans..." (English) Warner, Ottonian Germany, 171.

${ }^{267}$ Ibid.: “...eiusque licencia sub districta Bonifacii abbatis regula humiliter multo tempore conversatus, bono deguit exemplo. Postque cum permissu eisudem patris Prucorum mentes a Christo alienas freno sancte predicaciones edomare temptaret...” (English) Warner, Ottonian Germany, 171.

${ }^{268}$ Ibid.: “...cuspide perfossus nono Kalendas Maii capitis abscisione optatum semper martirium solus ex suis percepti absque omni gemitu..." (English) Warner, Ottonian Germany, 171.

${ }^{269}$ Ibid., 388: "In duodecimo conversionis ac inclitae conversationis suae anno ad Pruciam pergens, steriles hos agros semine divino studuit fecundare; sed spinis pululantibus horrida non potuit facile molliri. Tunc in confinio predictae regionis et Ruscia cum predicaret, primo ab incolis prohibetur et plus euvangelizans capitur deindeque amore Christi, qui aeclesiae caput est, XVI. Kal. Martii mitis ut agnus decollatur cum sociis suimet XVIII. Corpora tot martirum insepulta iacuerunt..." (English) Warner, Ottonian Germany, 300 . 
that Brun was hindered by the residents, seized after more evangelizing, and then "was beheaded, meek as a lamb, along with his own eighteen companions." 270 These victims were eventually honored by the most fair King Henry, and were saved in triumph by allpowerful God. $^{271}$

In both of these instances Thietmar neglected to provide more circumstances around the events. Who exactly killed these preaching bishops? An angry mob? Armed soldiers? What behavior or activity caused the bishops to be the victims of such violence, to the extent that they deserved to be beheaded? Furthermore, in Brun's case, the violence included his eighteen companions. Who were these companions? Fellow missionaries? His own armed contingent? Killing his eighteen companions suggests that a more violent episode occurred, involving a gang or perhaps a small army, but Thietmar did not provide these details. ${ }^{272}$ Did he assume his readers would understand the background, and did not find it necessary to convey it? If so, this might reveal a common understanding among the clergy regarding the risks of preaching in frontier territories to those who were only nominally or recently converted Christians. ${ }^{273}$ Due to Thietmar's location in a frontier diocese, this is a context in which he was exceedingly acquainted.

\footnotetext{
${ }^{270}$ Holtzmann, ed., Die Chronik des Bischofs Thietmar, 388: "In duodecimo conversionis ac inclitae conversationis suae anno ad Pruciam pergens, steriles hos agros semine divino studuit fecundare; sed spinis pululantibus horrida non potuit facile molliri. Tunc in confinio predictae regionis et Ruscia cum predicaret, primo ab incolis prohibetur et plus euvangelizans capitur deindeque amore Christi, qui aeclesiae caput est, XVI. Kal. Martii mitis ut agnus decollatur cum sociis suimet XVIII. Corpora tot martirum insepulta iacuerunt..." (English) Warner, Ottonian Germany, 300.

${ }^{271}$ Ibid.: "Facta sunt autem haec in tempore serenissimi regis Heinrici, quem Deus omnipotens triumpho tanti presulis honorificavit et, ut multum spero, salvavit." (English) Warner, Ottonian Germany, 300-301.

${ }^{272}$ Warner's footnote on p. 300 added that the Quedlinburg Annals recorded that Brun's martrydom occurred on March 9, 1009, referencing p. 80 of the Annales Quedlinburgensis, edited by G. Pertz, MGH, ss, vol. 3, pp. 22-90. Hanover.

${ }^{273}$ For more on the challenges, conflicts, and often violence Christian missionaries encountered when dealing with pagans on the eastern German frontier see Tellenbach, The Church in Western Europe, 1-21.
} 
However, it is important to note that, without adding other circumstances surrounding their death, Thietmar considered Archbishop Adalbert of Magdeburg and Bishop Brun of Merseburg martrys. In contrast, the surviving preacher, Adelbert of Trier, was not killed and therefore did not earn martrydom. Thietmar also did not extend praise to Adelbert on the basis of his preaching, despite the danger he faced by being expelled by those he had tried to convert. It seems that Thietmar was not impressed with missionary bishops who fled from rowdy heathens. Perhaps, as a frontier bishop himself, Thietmar had a lower tolerance for anything resembling cowardice in other bishops.

\section{Thietmar On Violent Clergy and Warfare}

Thietmar explicitly praised some cases of clerical violence and warfare in his Chronicon. While this view coincides with the honor culture of the tenth century, using battle to earn acclaim or honor seems to challenge the just war doctrine, which was that warfare was to be used only punitively. ${ }^{274}$ When praising warrior or militant bishops and clergy for killing in warfare, Thietmar condoned their actions. Not only that, but Thietmar also connected their success with divine favor and justice. In some instances, facing non-Christians earned the warrior bishop martyrdom, an important status that Thietmar even extended to the bishop's soldiers as well.

In one dramatic case of clerical warfare, not only did Thietmar show his approval through praising a warrior bishop, he also associated the bishop's fighting skills with his pastoral ability. This scenario involved Christians fighting non-Christian Hungarians in a defensive military campaign, the type which Thietmar thought most appropriate. Bishop

${ }^{274}$ Russell, The Just War in the Middle Ages, 19. 
Michael of Regensburg (941-972) helped lead an army from Bavaria who went to save the eastern regions from a band of Hungarians. Unfortunately for Bishop Michael, the German forces were demolished. ${ }^{275}$ After losing an ear and having suffered wounds in his limbs, Bishop Michael lay among the fallen as if he were dead. ${ }^{276}$ When an enemy soldier noticed the bishop, he tried to finish him off with a lance. ${ }^{277}$ But God intervened and strengthened the bishop, allowing him to kill his enemy after a long struggle. ${ }^{278}$ Eventually the bishop returned home, where he received praise and honor by all who knew Christ, even the clergy. ${ }^{279}$ Indeed, upon returning "the good soldier is received by all in the clergy, and he is recognized as the best pastor in the people he is protecting, and his mutilation was not to shame, but more to honor. ${ }^{280}$ This tale contains an epic feel, with the returning bishop praised not only as a hero by his people, but also lauded by other clergy for being the best pastor and protecting his flock. Not only that, his lost ear and other wounds earned him even more honor. Finally, the bishop was victorious in his duel against the Hungarian through strength from God. However, the bishop did not pray or perform a rite to receive God's blessing, it came while he fought for his life. God saw fit to strengthen him even without being asked to do so through prayer or ritual.

\footnotetext{
${ }^{275}$ Holtzmann, ed., Die Chronik des Bischofs Thietmar, 72: "Qui cum commissa sibi optime diu regeret, commoventibus iterum orientales Ungris, cum caeteris Bawariorum principibus his ad succerrendum venit. Sed exorto mox inter eos duello, pro dolor! Nostri victi ab hostibus atque prostrati sunt." (English) Warner, Ottonian Germany, 112.

${ }^{276}$ Ibid.: "Episcopus autem, abscisa suimet auricula et caeteris sauciatus membris, cum interfectis quasi mortuus latuit." (English) Warner, Ottonian Germany, 112.

${ }^{277}$ Ibid.: "Iuxta quem inimicus homo iacens et hunc vivere solum ab insidiantium laqueis tunc securus cernens, hastam sumpsit et necare eundem conatus est." (English) Warner, Ottonian Germany, 112.

${ }^{278}$ Ibid.: "Tunc iste confortatus in Domino post longum mutui agonis luctamen victor hostem prostravit et inter multas itineris asperitates incolomis notos pervenit ad fines." (English) Warner, Ottonian Germany, 112.

${ }^{279}$ Ibid.: “... et inter multas itineris asperitates incolomis notos pervenit ad fines. Inde gaudium gregi suo exoritur et omni Christum cognoscenti." (English) Warner, Ottonian Germany, 112.

${ }^{280}$ Ibid.: "Excipitur ab omnibus miles bonus in clero et servatur optimus pastor in populo, et fuit eiusdem mutilatio non ad dedecus, sed ad honorem magis." (English) Warner, Ottonian Germany, 112.
} 
In another instance of clerical warfare against non-Christians, Thietmar praised

this warfare and the bishops who participated, and also highlighted that they had received divine sanction for their actions. In response to the Slav uprising in 983, local bishops and nobles led an army to counter about thirty bands of Slav warriors who were ravaging the lands. ${ }^{281}$ After gathering their army, the defenders conducted morning mass, an activity which earned them divine strength for their upcoming combat. ${ }^{282}$ In Thietmar's words,

The bishops Gisilerus and Hildeward came together with the lesser marquis Diderico and the rest, with comrades Ricdago, Hodone and Binizone, Fritherico, Dudone, also my father Sigifried and others with many men, who, on the day the Sabbath first dawned, all heard mass and fortified body and soul, confidently struck down the enemies on one hill. Only a few broke to flee. ${ }^{283}$

Those who returned from the battle rejoiced with people they met along the way and at home. ${ }^{284}$ Furthermore, these heroic defenders earned the most important praise of all: God's praise, which was earned by defeating enemies who scorned God and who were

\footnotetext{
${ }^{281}$ Holtzmann, ed., Die Chronik des Bischofs Thietmar, 120-122: "Desolatis tunc omnibus preda et incendio urbibus ac villis usque ad aquam, quae Tongera vocatur, convenerunt e Sclavis peditum ac equitum plus quam $\mathrm{XXX}$ legiones, quae sine aliqua lesione residua quaeque suorum auxilio deorum tunc devastare non dubitarent, tubicinis precedentibus. Conveniunt episcopi Gisillerus et Hilliwardus cum marchione Thiedrico caeterisque comitibus, Ricdago, Hodone et Binizone, Fritherico, Dudone ac patre meo Sigifrido aliisque compluribus; qui ut dies sabbati primo illuxit, missam omnes audiunt, corpus animamque caelesti sacramento muniunt hostesque obvios fiducialiter inrumpentes, paucis in unum collem effugientibus, prosternunt." (English) Warner, Ottonian Germany, 142-143.

${ }^{282}$ Ibid.: "Conveniunt episcopi Gisillerus et Hilliwardus cum marchione Thiedrico caeterisque comitibus, Ricdago, Hodone et Binizone, Fritherico, Dudone ac patre meo Sigifrido aliisque compluribus; qui ut dies sabbati primo illuxit, missam omnes audiunt, corpus animamque caelesti sacramento muniunt hostesque obvios fiducialiter inrumpentes, paucis in unum collem effugientibus, prosternunt." (English) Warner, Ottonian Germany, 142-143.

${ }^{283}$ Ibid.: "Conveniunt episcopi Gisillerus et Hilliwardus cum marchione Thiedrico caeterisque comitibus, Ricdago, Hodone et Binizone, Fritherico, Dudone ac patre meo Sigifrido aliisque compluribus; qui ut dies sabbati primo illuxit, missam omnes audiunt, corpus animamque caelesti sacramento muniunt hostesque obvios fiducialiter inrumpentes, paucis in unum collem effugientibus, prosternunt." (English) Warner, Ottonian Germany, 142-143.

${ }^{284}$ Holtzmann, ed., Die Chronik des Bischofs Thietmar, 122: “Omnes autem nostri, exceptis tribus, crastino guadentes remeabant, applaudantibus cunctis, quos obviam habuere vel domi invenere.” (English) Warner, Ottonian Germany, 143.
} 
also idolators. ${ }^{285}$ In fact, the Slavs were defeated because they ignored God: "Wondrous God praised the victors in all his works, and was justifying of Paul the teacher's word; it is not wisdom nor strength to counsel against God."286 When mentioning that the defenders conducted mass, Thietmar made a point to link this sacrament with the defenders' successful attack against the Slav invaders. This is like the case with Bishop Michael, who received God's strength after being wounded on the battlefield and survived one-on-one combat as a result. But in this case, the defenders fortified themselves with mass and received a blessing before the battle, and then defeated the enemy. In return, the defenders received approval from everyone along their way home, and they even earned God's praise. In addition, Thietmar named two of the bishops who participated in the defense, Giselher and Hildeward, and by doing so, may have been singling them out for additional honor.

In one instance, Thietmar awarded martyrdom not only to the bishop who led the campaign, but also to his soldiers after being defeated by an enemy army. Furthermore, Thietmar used divine imagery to add holiness to their sacrifice. Bishop Arn of Würzburg (855-892) was returning from his campaign in Bohemia with his army and set up camp along a river. ${ }^{287}$ While he was celebrating mass, presumably with his army, they were "surrounded by hostile troops and all were sent forward, having caused martyrdom to

\footnotetext{
${ }^{285}$ Ibid.: "Laudatur a victoribus in cunctis Deus mirabilis operibus, approbaturque veredicus Pauli doctoris sermo: Non est prudentia neque fortitudo nec consilium adversus Dominum. Derelicti sunt, qui prius Deum spernere presumpserunt idolaque manufacta et prorsus inania creatori suo stulti preposuerunt." (English) Warner, Ottonian Germany, 143.

${ }^{286}$ Ibid.: "Laudatur a victoribus in cunctis Deus mirabilis operibus, approbaturque veredicus Pauli doctoris sermo: Non est prudentia neque fortitudo nec consilium adversus Dominum." (English) Warner, Ottonian Germany, 143.

${ }^{287}$ Holtzmann, ed., Die Chronik des Bischofs Thietmar, 6: "Sed non longe a predicto amne in pago Chutizi dicto Arn, episcopus Sanctae Wirciburgiensis aecclesiae, ab expeditione Boemiorum reversus et iuxta plateam in parte septentrionali, fixo super unum collem suimet tentorio..." (English) Warner, Ottonian Germany, 69.
} 
him, and to his companions, theirs." ${ }^{288}$ The scene is a massacre, and Thietmar's following description adds a note of divine mythicality and timelessness that elevates their sacrifice: "There today bright lights are often seen, and not even Slavs are doubting these to be the holy martyrs of God." ${ }^{289}$ It is not clear who the hostili are, but Bohemians seem likely, based on their proximity to Würzburg. If so, this means the enemy soldiers could be considered non-Christians. In contrast to Bishop Michael of Regensburg's martrydom, however, Thietmar did not write that Arn had been engaged in personal combat while being surrounded and massacred. Perhaps this is a lack of information in the source material, or it indicates that Thietmar chose to highlight that Bishop Arn was celebrating mass during his martyrdom, instead of actively fighting. This distinction may be significant-was Thietmar highlighting Bishop Arn's function as a religious man, instead of portraying him as a warrior, dying among a heap of heathen enemies? Finally, Thietmar clearly marked their martyrdom as a timeless sacrifice, meant to praise God in a way that even the heathen Slavs could not deny. The lights memorialize their sacrifice, and mark its divinity and purity.

However, not all warrior bishops earned Thietmar's praise, even when fighting non-Christians. In one stark case Thietmar complained about Archbishop Gisilher, who had failed to defend his city and territory properly. He wrote in a moralizing style, perhaps meant to provide an instructive lesson to his readers: "Let us recall to memory what befell wretched Archbishop Gisilher and his property because of his

\footnotetext{
${ }^{288}$ Ibid.: “...cum missam caneret, hostili circumvallatus agmine, premissisque omnibus per martirium suimet consociis, semet ipsum optulit..." (English) Warner, Ottonian Germany, 69.

${ }^{289}$ Ibid., 8: “...ubi hodie sepe accensa videntur luminaria; et sanctos Dei martires hos esse nec Sclavi dubitant." (English) Warner, Ottonian Germany, 69.
} 
carelessness. ${ }^{290}$ The archbishop was assigned by the emperor to defend the city of Arneburg, which had been fortified as an important position in order to defend the country. ${ }^{291}$ Thietmar's tone with this line is the same as in other cases throughout his text, regarding the expected military role that bishops were to play. It is unremarkable that a bishop had been assigned to defend a strategic fortification. The exception is that, in this case, Archbishop Gisilher failed in his assignment, and with drastic consequences. The archbishop was called by the Slavs to meet, and left the city with a group of his soldiers. ${ }^{292}$ However, the archbishop and his soldiers were ambushed by men from the forest. ${ }^{293}$ While the archbishop's escape by horse may have been deemed shameful by Thietmar, he did not offer this judgment overtly. ${ }^{294}$ However, his account of the victorious Slavs, who pillaged the dead and complained of the bishop, contains an implicit taunt regarding the bishop's mistake: "The victorious Slavs pillaged the bodies of the slain on the six Nones of July without any danger, and thus became masters of the archbishop and deplored him."295 Thietmar may be criticizing Archbishop Gisilher's inability to defend his people through a gibe delivered by the enemy, the victorious Slavs, and therefore commenting upon his failure as military commander and secular defender of his people.

\footnotetext{
${ }^{290}$ Holtzmann, ed., Die Chronik des Bischofs Thietmar, 175: "Revocemus ad memoriam, quod miserabiliter Gisilero archipresuli incuria sui dampnum contigit." (English) Warner, Ottonian Germany, 178.

${ }^{291}$ Ibid.: "Imperator ob defensionem patrie Hornaburg civitatem opere muniens necessario, eam quatuor ebdomadas ad tuendum huic commisit." (English) Warner, Ottonian Germany, 178.

${ }^{292}$ Ibid.: "Qui fraude ignota ad placitum a Sclavis vocatus cum parva multitudine exiit." (English) Warner, Ottonian Germany, 178.

${ }^{293}$ Ibid.: "Ecce autem, unus e consociis eiusdem a silva erumpere hostes prodidit." (English) Warner, Ottonian Germany, 178.

${ }^{294}$ Ibid.: "Congredientibus vero tunc ex utraque parte militibus archiantistes, qui curru venit, equo fugit allato, ex suis mortem paucis evadentibus." (English) Warner, Ottonian Germany, 178.

${ }^{295}$ Holtzmann, ed., Die Chronik des Bischofs Thietmar, 175: "Sclavi victores preda interfectorum sexto Nona Iulii sine periculo pociuntur et archiepiscopum sic elabisse conqueruntur." (English) Warner, Ottonian Germany, 178.
} 


\section{Thietmar on Violent Clergy and Feuding}

Feuding was a common occurrence in Thietmar's Chronicon and often involved clergy, and examining these cases demonstrates the challenges Thietmar faced as a bishop in his society. ${ }^{296}$ While Thietmar could find feuding violence by bishops justifiable and valid, in other instances he also found it pointless, which shows that he favored social order. In a feud between Count Wichmann of Vreden and Count Balderich of Drenthe ${ }^{297}$ Thietmar characterized Count Wichmann as a helpful man for the country, ${ }^{298}$ who routinely defeated his opponent-Count Balderich, whom Thietmar said humiliated himself-in battles during their long-running struggle. ${ }^{299}$ Thietmar did not mince words when he expressed his dislike for Count Balderich's "maneuvering between the other nobles with great disgrace." ${ }^{300}$ Therefore, when Count Wichmann was killed, that sad news spread broadly ${ }^{301}$ and spurred Bishop Dietrich of Münster (1011-1022) to gather forces to avenge his death: "Next, having sent his own messengers through all regions, he stirred up his own relations and those from the same province to avenge this person., ${ }^{302}$ Bishop Dietrich then attacked Count Balderich's lands: “Accordingly, with a strong (valida) hand he seized the city of the aforementioned enemy, Upplan by name,

\footnotetext{
${ }^{296}$ Fichtenau devotes a chapter in Living in the Tenth Century to the topic of war and feuding, 417-434.

297 A well-known feud recounted in more detail by Alpert of Metz, On the Variety of Our Times, and also discussed by Reuter in "Peace-Breaking, Feud, Rebellion, Resistance," 355-388.

${ }^{298}$ Holtzmann, ed., Die Chronik des Bischofs Thietmar, 456: "Insuper Wigmannus comes utilis in omnibus patriae..." (English) Warner, Ottonian Germany, 340.

${ }^{299}$ Ibid.: "Inter predictum et comitem Baldricum longa fuit contentio, quae Baldricum sepe in prelio devictum mutuo in tantum humiliavit..." (English) Warner, Ottonian Germany, 340.

${ }^{300}$ Ibid.: “...ut inter caeteros primates cum magno versaretur dedecore.” (English) Warner, Ottonian Germany, 340.

${ }^{301}$ Holtzmann, ed., Die Chronik des Bischofs Thietmar, 457: "Miseria talis fama vulgante dilatatur..." (English) Warner, Ottonian Germany, 341.

302 Ibid., 457-458: "Dehinc missis per omnem regionem suis nunciis comprovinciales et affines suos ad hec vindicanda excitat.” (English) Warner, Ottonian Germany, 341.
} 
laying waste and consuming by fire the surrounding areas." 303 Thietmar's use of the adjective valida in association with Bishop Dietrich's use of force in this case highlights the fact that he found Dietrich's response warranted and justified, a point demonstrated further in Thietmar's subsequent statement. After praising Bishop Dietrich's "strong/valid hand" in destroying Count Balderich's lands and seizing his city, Thietmar criticized Bishop Dietrich for an empty feud with Count Herman in that same year, resulting in them laying waste to each other's properties. ${ }^{304}$ Because Thietmar praised and validated Bishop Dietrich for avenging Count Wichmann, and then disagreed with his actions in another feud, Thietmar revealed that he saw the clerical feuder's intention as important. In other words, feuding violence conducted by bishops and the clergy was not always warranted, but there were times when it absolutely was.

While Thietmar found some instances of clerical feuding justified, he took care to distinguish between secular and divine roles in another. Thietmar wrote about Liudolf, a priest who avenged his brother's murder by taking up arms and causing much harm to the people ${ }^{305}$ but not before Liudolf “put down his priestly office." ${ }^{306}$ Liudolf's action implies that he thought that violence was not appropriate in his spiritual capacity, and he demonstrated that his clerical identity represented a sacred office that he was unwilling to defile when taking up arms for retribution. After Liudolf's acts of vengeance against their

\footnotetext{
${ }^{303}$ Ibid.: "Itaque cum valida manu urbem predicti hostis nomine Upplan possedit, contigua devastans loca et igne consumens." (English) Warner, Ottonian Germany, 341.

304 Ibid., 458: "In hoc autem anno Thiedricus antistes et Hirimannus comes, Gerbergae filius, de inani re mutuo certantes sua vastabant." (English) Warner, Ottonian Germany, 342.

${ }^{305}$ Holtzmann, ed., Die Chronik des Bischofs Thietmar, 205. "Cuius maritus antea a fratribus geminis Ugione et Ufficone occisus occubuit quinto Kalendas Ianuarii. Huius frater Luidolfus nomine, deposito clericatu arma sumpsit ultricia multumque nostris nocuit, captus autem a cesare iterum gradui pristino restitutus est." (English) Warner, Ottonian Germany, 196.

${ }^{306}$ Ibid.: "Cuius maritus antea a fratribus geminis Ugione et Ufficone occisus occubuit quinto Kalendas Ianuarii. Huius frater Luidolfus nomine, deposito clericatu arma sumpsit ultricia multumque nostris nocuit, captus autem a cesare iterum gradui pristino restitutus est.” (English) Warner, Ottonian Germany, 196.
} 
people, Thietmar reported that the emperor captured him and restored him to his previous status. ${ }^{307}$ Liudolf apparently held no personal compunction for resuming his clerical duties after killing people, and by restoring him, neither did the emperor. Thietmar did not provide his own thoughts on this event, however he did not criticize either party for its behavior. However, by reporting that Liudolf had discontinued his priestly office, Thietmar may have been noting the incommensurate nature of feuding violence and the priesthood. This was likely Thietmar's way of indicating that he thought other clergy either ought to avoid feuds, or at least quit their office before engaging in them. It is also notable that this is the only instance where Thietmar recorded that a cleric quit his post before conducting any type of violence. This might be a suggestion for his readers to consider before conducting their own feuds.

Thietmar wrote about his own feuds, and used these opportunities to further express his disappointment and exasperation with feuding nobles and clergy. Two passages in particular later in his Chronicon revealed much about his attitude regarding this type of violence. In a feud of his own with Margrave Ekkehard and his brother in 1018, although Ekkehard and his brother had both promised peace with Thietmar, "each of the two did not keep to this well. ${ }^{, 308}$ After breaking their word, Ekkehard and his brother's soldiers harmed Thietmar's people and damaged his buildings, actions which proved how lords needed protection from others. ${ }^{309}$ To further demonstrate his point,

\footnotetext{
${ }^{307}$ Ibid.: "Cuius maritus antea a fratribus geminis Ugione et Ufficone occisus occubuit quinto Kalendas Ianuarii. Huius frater Luidolfus nomine, deposito clericatu arma sumpsit ultricia multumque nostris nocuit, captus autem a cesare iterum gradui pristino restitutus est." (English) Warner, Ottonian Germany, 196.

${ }^{308}$ Holtzmann, ed., Die Chronik des Bischofs Thietmar, 519. "Quam cum Ekkihardus ex sua parte promitteret et frater suus a me diu desideratus a Polenia veniens dextera manu sua pacifica promitteret, uterque hanc non bene servavit." (English) Warner, Ottonian Germany, 376.

${ }^{309}$ Ibid.: "Namque homines sex flagellati et depilati cum edificiis turpiter mutilatis approbant, qualiter tales seniores ab aliis precaveri debeant.” (English) Warner, Ottonian Germany, 376.
} 
Thietmar wrote that these men also attacked other clergy: "Their vassals not only raged against me in their customary manner, but truly even harmed others who were better. And indeed they attacked the Archbishop Gero of Cologne in Werben, and Count Siegfried in Nishwitz and they took whatever amount was pleasing to them." ${ }^{310}$ Thietmar's frustration exudes a sense of powerlessness, even on the part of an archbishop and a count, who were also targets of Ekkehard and his brother's vassals. This frustration continues into the subsequent chapter, where Thietmar vented in a rather lengthy passage about how even insignificant transgressions between neighbors resulted in destruction and plundering. ${ }^{311}$

No amount of restitution or amends could prevent violent feuds from escalating, and left Thietmar wondering how bishops were expected to defend themselves against these transgressions without resorting to violence themselves. ${ }^{312}$

A final example of feuding and clerical violence sits in stark contrast to Thietmar's previous lamentation, because in this case, Thietmar and his allies were the instigators instead of the victims. In 1010, King Henry II made peace with his enemies, ${ }^{313}$ but after having suffered repeated insults and property damage from Boleslav Chrobry, Duke of Poland, Henry changed his mind and ordered a fierce campaign against him after

\footnotetext{
${ }^{310}$ Ibid.: 519-520. "Satellites eorum more solito in me modo exarsere, verum etiam aliis melioribus nocuere. Archiepiscopum etenim Geronem in Wirbini et Sifridum comitem in Nicici pecierunt et, in quantum eis placuit, abstulerunt." (English) Warner, Ottonian Germany, 376.

311 Ibid.: 520. "Superbia seniorum instigat furorem satellitum et, quia hiis sufficit, equales sibi alios in hiis partibus esse non permittit. Si aliquis vicinus non sponte sua erga eos ex improviso delinquit, non est eis emendacio condigna acceptabilis et post recompensacio invincibilis. Et per hoc flagellum vicini graviter concuciuntur, ut non contra se alii, sive rectum habeant sive non, nequaquam eleventur." (English) Warner, Ottonian Germany, 376-377.

${ }^{312}$ Ibid.: "Episcopus in hiis partibus constituti ab eorum potentia sunt nimium depressi; et nos eorum procuratores, si contra Deum et iusticiam eius voluntati eorum in cunctis satisfacimus, honorem et aliquam utilitatem habemus; sin autem, contempnimur et, sicut nobis nullus aut regnet aut imperet dominus, depredamur." (English) Warner, Ottonian Germany, 376-377.

${ }^{313}$ Holtzmann, ed., Die Chronik des Bischofs Thietmar, 343-344: "Rex autem, in hac estate et proxima hieme consilio et virtute pacificatis hostibus, contumelias et dampna a Bolizlavo sibi illatum crebra meditatione revolvit et post pascha expedicionem suam atroci iussione indixit." (English) Warner, Ottonian Germany, 276.
} 
Easter. ${ }^{314}$ The army included Thietmar, and was led by Duke Bernhard and Provost

Waltherd-later joined by Jaromir, the celebrated Duke of Bohemia-and met at the agreed upon location in lands belonging to Margrave Gero, who was an ally. ${ }^{315}$ From there,

Duke Bernhard and provost Waltherd "went ahead for the sake of winning over Boleslav, and finding nothing there that pleased them, turned back."316 One can assume that the duke and the cleric were expecting to encounter resistance or find something worthwhile to plunder. Thietmar's use of the phrase "finding nothing there that pleased them"317 may reinforce the idea that they were looking for plunder, or it implies that the group encountered trouble. Taken more literally, it may also mean that what they saw put them on their guard or threatened their safety. Whichever scenario occurred, that reason provides the potential motive for their subsequent actions. Next, Thietmar reported something interesting. In a manner reminiscent of a confessional, he wrote:

Nor can I neglect that exceedingly miserable thing that happened in the same place, to that aforementioned count. All of us-I cannot exclude anyone-were enemies to this man instead of friends, and excepting his dependents, we destroyed everything and certain things by fire. Of this matter, the king was neither avenger nor defender. $^{318}$

\footnotetext{
${ }^{314}$ Ibid.: "Rex autem, in hac estate et proxima hieme consilio et virtute pacificatis hostibus, contumelias et dampna a Bolizlavo sibi illatum crebra meditatione revolvit et post pascha expedicionem suam atroci iussione indixit." (English) Warner, Ottonian Germany, 276.

${ }^{315}$ Ibid.: 344. "Fit conventus in Belegori, quod pulcher mons dicitur, in Geronis predio marchionis. Tunc Bernhardus dux et Waltherdus prepositus gratia Bolizlavum convertendi precesserunt ac nil ibi, quod sibi placeret, invenientes reversi sunt. Venit etiam huc Iarimirus, Boemiorum dux inclitus et regi per omnia fidelis." (English) Warner, Ottonian Germany, 276.

316 Ibid.: "Tunc Bernhardus dux et Waltherdus prepositus gratia Bolizlavum convertendi precesserunt ac nil ibi, quod sibi placeret, invenientes reversi sunt.” (English) Warner, Ottonian Germany, 276.

${ }^{317}$ Ibid.: “. . ac nil ibi, quod sibi placeret, invenientes reversi sunt.” (English) Warner, Ottonian Germany, 276.

${ }^{318}$ Holtzmann, ed., Die Chronik des Bischofs Thietmar, 344: "Nec preterire possum, quod miserabile nimis predicto comiti ibidem accidit. Nos omnes-nec aliquem excipere valeo-vice amicorum hostes huic fuimus exceptisque dumtaxat mancipiis omnia consumpsimus et quaedam igne. Huius rei nec rex ultor seu defensor fuit." (English) Warner, Ottonian Germany, 276.
} 
Bishop Thietmar seems to have written that statement with a heavy hand, and his confession is striking in its forthrightness. It reveals several things. The first is that Thietmar's statement regarding this apparently unwarranted attack on an admitted "friend" helps bolster the Chronicon's overall veracity as a historical source. Keep in mind that Thietmar could have modified this account in any number of ways, not the least of which included a complete omission. While it is uncertain how much he wrestled with his actions and participation, or how seriously he considered not writing about it, the point is that he did, and he did not have to. Furthermore, he included himself among the perpetrators of this unwarranted attack on an ally and vassal of his king.

More importantly, this account illuminates the role that violence played in society and its context in Thietmar's age. An army led by a group of nobles and a bishop attacked the lands of one of their colleagues, himself King Henry II's vassal, and destroyed them by fire. One must wonder how many times an incident like this one occurred and had not been reported. This attack also demonstrates a grim reality that is easy to take for granted; that any armed group of men had the capacity for random violence and destruction, even when led by nobles and bishops. Furthermore, that if there was no enemy nearby, then one could be found or manufactured. It also demonstrates the amount of agency that people had when making decisions and acting. Despite political and social efforts to curtail violence, especially when conducted by members of the clergy, in this case men ignored both canon law and just war traditions and acted on their own impulses and initiative. While Thietmar's description of the level of destruction is brief, witnessing it was probably awe-inspiring, perhaps frightening. Or alternatively, given the fact that the 
leaders of this attack were men that had witnessed battles and destruction on this level several times already, its horror for Thietmar may have resided in its banality.

It is also notable that Thietmar ended his account by stating that the king did not provide protection for the perpetrators, nor did he pursue retribution on the victim's behalf. Attacks such as this one were reported by Thietmar several times as causes for feuding, and perhaps the king's unwillingness to resolve this situation is one explanation for feuding's continued role. Thietmar's emphasis on the king's reaction to this episode shows that Thietmar recognized the potential repercussions of his participation in this act. However in this case the repercussions did not come in the form of legal or political punishment from King Henry II. The king's inaction is a display of the place that violence occupied in his realm.

Thietmar's thoughts and feelings regarding clerical warfare and violence were situational and based upon intent. He allowed praise for bishops who led victorious military campaigns, especially in self-defense, and when against non-Christians. In another instance he praised clerical warrior skills and equated warrior ability with pastoral care. In other instances he described divine sanction for warfare that was about to occur, showing that militant Christian behavior could be approved by God. In these instances, Thietmar's views more or less matched the traditional just war philosophy and the social condition he existed in. Thietmar saw violence as an acceptable means to enact justice, even when done for revenge or protection. Moreover, violence was most appropriate when conducted by an authority figure or when approved by God. These views were expressed in his writings on the rebellious Slavs, who deserved their annihilation at the hands of an army led by bishops. 
Most importantly, in many cases of clerical warfare and violence described by Thietmar, the bishop or clergyman is showcased playing a key military role-not a supporting, spiritual one. Whether at the head of an army, taking responsibility for defending a city or territory, or fighting off Hungarians or Slavs, bishops and other highranking clergy are shown in a military leadership capacity, and not once did Thietmar criticize them for playing such a role. However, there were times when Thietmar judged them based upon their ability to perform this responsibility. 


\section{Chapter 5}

\section{Conclusions: Thietmar the Pragmatic Bishop}

The examination of the historiography of clerical warfare performed earlier in this paper revealed a few key themes. One theme covered the clergyman's multi-faceted place in his society, culture, and political sphere, and how those systems not only fueled the clergymen's upbringing and worldview, but also how those factors influenced his behavior during his career. One component of this scholarship most important to this study is the point of view taken by scholars, like Heinrich Fichtenau, Timothy Reuter, and Rosamond McKitterick, who have demonstrated that bishops acted, and were expected to act, as both a secular and spiritual figure. Furthermore, the bishop's role included spiritual guidance and religious duties; but the bishop also served in an administrative, military, and political capacity. Indeed, one should think of the medieval German bishop/archbishop as something closer to a State or Provincial governor in a theocratic state, rather than a purely religious or spiritual leader.

A second theme introduced earlier in this paper was the study of clerical warfare and violence as a phenomenon. As noted by Friedrich Prinz and others, priests, bishops, and clergy participated in violence and warfare for a variety of reasons, often at the head of an army or armed band. Besides the military actions of bishops and clergy, David Bachrach expounded upon the religious duties clergy performed on the battlefield, which were intended to provide military benefits. These rituals were meant to cleanse warriors' souls, assuage their community's grief from combat deaths, and help dispel their fears that their fallen warriors would be forgiven and their souls allowed into Heaven. Violence 
played a prevalent role and function in society during the so-called Age of Iron. Among the types of violence studied by scholars in this area are feuding, rebellion, and warfare. Scholars have concluded that these types of violence and warfare performed functions in society that went beyond simple destruction for its own sake. These functions included projecting power, communicating grievances, exacting justice, and conflict resolution. In this regard, violence and warfare were pervasive in this age, which perhaps lead those who lived in this condition to become desensitized to violence and its effects.

Over time, the Church responded to this violence and attempted to stop it, or at least contain it. Lawrence Duggan described the Church's attempts to curb not only clerical violence but also secular violence through synods and canon law, efforts which began in earnest by the mid-eleventh century. One unintended consequence of these efforts, according to Carl Erdmann, was that through this process, the Church began to own the narrative regarding violence, become comfortable with it, and then, over time, develop the idea of crusade and just war as a result. Erdmann deftly described this course and its destination as one arrived at through pragmatism and accident, where the Church's attempts to curtail violence led to its leaders placing violence and its use under their authority. Meanwhile, it also issued canon law forbidding clerical armsbearing in the mid-eleventh century, acts that were part of the Gregorian reforms. Despite the reforms to restrict clerical armsbearing in the mid-eleventh century, Duggan notes that "there is much conflicting evidence on the views of churchmen towards arms and warfare in the ninth, tenth, and eleventh centuries." 319 Therefore, discovering how an individual bishop felt, rationalized, justified, or managed violence and his participation in it will

${ }^{319}$ Duggan, Armsbearing and the Clergy, 98. 
help alleviate some of this confusion. This is where Thietmar of Merseburg's voice provides valuable insight.

In the spirit of medieval German scholar Timothy Reuter, who highlighted the need to study the Ottonian sources on their own terms, ${ }^{320}$ and examine the sources with the goal of understanding them within their contexts, including their authors, ${ }^{321}$ this paper's goal is to develop an understanding of how a medieval German bishop thought of clerical violence and warfare. How much did it occur? Was it considered good or bad? What can this tell us about the relationship between bishops and violence in this era? Answering these types of questions through the writings of Thietmar of Merseburg can lead to further lines of inquiry, specifically surrounding comparative viewpoints on clerical warfare and violence. For example, were Thietmar's views on clerical warfare and violence unique? Examining these issues will also help us get to know these people as individuals, and comprehend their culture.

Examining evidence from Thietmar of Merseburg's Chronicon reveals much about clerical violence in his experience. First, with sixty-five incidents of clerical warfare and violence recorded by Thietmar, it is safe to conclude that clerical participation was not an anomaly. Indeed, short of conducting a more involved quantitative analysis, one may reason with confidence that clerical warfare and violence appeared as a significant proportion of all violence and warfare recorded by Thietmar of Merseburg. However, this point should not be taken too far without further examination. Thietmar may not have written about every violent episode he encountered, and he also may not have recorded each episode with complete accuracy. With these qualifiers in

\footnotetext{
${ }^{320}$ Reuter, "Introduction: Reading the Tenth Century," 14.

${ }^{321}$ Reuter, Germany in the Early Middle Ages, 7.
} 
mind, however, the fact remains that clerical violence and warfare occurred with some regularity throughout Thietmar's life, and it was part of his historical memory and tradition, both as a secular figure and a religious leader.

Secondly, in terms of Thietmar's general thoughts on clerical warfare and violence, not once in these sixty-five occurrences did Thietmar take a definitive stand against a member of the clergy conducting violence or warfare. He did not say that it was sinful, evil, nor even non-desirable. Furthermore, Thietmar did not cite any church synod or canon law stating this view. On the contrary, Thietmar found clerical violence and warfare praiseworthy, pragmatic, or honorable, based on the circumstances. But his attitude also contained nuance and often a bit of anxiety. With this in mind, Thietmar's general attitudes towards clerical violence demonstrate that he had embraced militaristic and pragmatic behaviors and morals for bishops and other clergy. This attitude validates David Warner's reference to Thietmar as a 'worldly,' militaristic 'frontier bishop'. ${ }^{322}$

Violence was part of Thietmar's life, and he did not exempt these episodes from his Chronicon. Its regular occurrence and his often nonchalant accounting of violent events can be numbing. For those living in this age, violence may have seemed impossible to escape, and this could have influenced Thietmar's pragmatic outlook on clerical violence. Supporting this conclusion are the many curt mentions of bishops, abbots, or other clergymen defending their cities from attack, leading an army, or participating in a violent conflict. When describing tenth-century violence and disorder, Heinrich Fichtenau wrote that "Legitimate force was accepted as the natural means to re-

${ }^{322}$ Warner, Ottonian Germany, 60. 
establish order where other means had failed. ${ }^{, 323}$ This idea echoes Thietmar's pragmatic view on clerical violence, and provides an angle that may explain why he wrote nonchalantly about clerical violence and warfare. It also may partially explain the source of his worldliness and pragmatism. In this regard Thietmar seems like a realist, an attitude made more interesting coming from a religious man trained in ecclesiastical studies.

Thietmar's accounts of clerical warfare and violence often emphasized the clergy's role as military leaders. Therefore, Thietmar's commentary regarding their actions often pertained to their performance in this capacity. When he praised them, it resulted from their military prowess in fighting or leadership. When he condemned them, he did so as a result of their failure in defending themselves or their territory. Rarely did Thietmar pay attention to a militant clergyman's spiritual or religious duties or character in these instances, which makes the times he did much more unique. Two examples stand out. One is the mission to destroy the fortifications at Schweinfurt during the rebellion against Henry II, where Bishop Henry of Würzburg and Abbot Erkanbald of Fulda followed their love of Christ over their secular concerns. The second example occurred when the priest Liudolf quit his priestly office and then avenged his brother's murder through force of arms. This instance contains the tertiary component, that Liudolf was allowed to resume his position afterwards, a result that Thietmar did not overtly praise nor condemn. Therefore one may conclude he found it acceptable. It is clear that Thietmar appreciated and agreed with Bishop Henry of Würzburg's and Abbot Erkanbald of Fulda's paying heed to their religious concerns over their secular ones, and that he held

${ }^{323}$ Fichtenau, Living in the Tenth Century, 417. 
them in high esteem as a result. Ironically, Thietmar praised them for acting like clergy who still accomplished their mission, but in a way that did not involve the target burg's complete destruction. He praised them for being militant clergy who retained their love for Christ. These clergy were examples of how to combine virtues in both the secular and spiritual spheres, and operate in a successfully united role.

Thietmar did not give militant bishops and clergy a free pass to conduct violence, and these are instances where Thietmar displayed his anxiety over clerical warfare and violence. By emphasizing clergy abandoning their clerical garb before committing murder, and other clergy acting according to their love of Christ as opposed to their secular obligations, Thietmar showed that clerical violence was not always justified. One's intention when committing violence mattered, especially for a member of the clergy. Acts of revenge required abandonment of one's clerical position, even if only temporarily. Bishops acting on behalf of their king to put down rebels were honorable for not completely destroying a rebel's territory, merely removing their fortifications. Bishop Dietrich of Münster was justified-and even praised-for attacking Count Balderich's lands in his response to the count's actions in murdering Count Wichmann during their longrunning feud. However, when Bishop Dietrich participated in his own feud, Thietmar condemned the bishop's violent behavior, finding it empty and wasteful. Therefore, he judged clerical violence based on intent and circumstances, and did not distinguish between secular or spiritual actions. He also did not justify militant clergy in every case of violence and warfare; he was not a blind propagandist for a militant church.

Indeed, Thietmar was a torn individual, struggling with his religious convictions while living in a world where violence occurred. As described earlier, Thietmar lamented 
that violent feuds often escalated, and that they involved the nobility and clergy. This reality left Thietmar wondering in exasperation how bishops were expected to defend themselves against these actions without resorting to violence themselves. ${ }^{324}$ On the other hand, Thietmar himself participated in feuding violence, when he was among those who raided, burned, and pillaged the lands of their friend, Margrave Gero. ${ }^{325}$ Admitting to this episode caused Thietmar a great deal of shame. Thietmar's actions in that episode should be considered alongside his statement earlier in his Chronicon, where he condemned violence between Christians-such as rebellions and feuds-and instead proposed that their soldiers be sent to fight in foreign wars, like their ancestors had done. ${ }^{326}$ Thietmar provided memorable examples for his readers which aptly demonstrated this position, such as Bishop Michael of Regensburg, who had defeated an enemy Hungarian in single combat, ${ }^{327}$ and Bishop Arn of Würzburg, who was martyred by Bohemians along with his army while conducting mass beside a river. ${ }^{328}$ Those two examples specifically included an epic, mythical tone, reminding one of a heroic foundation story. In both cases divine support or intervention provided the bishops with additional justification and support, so

\footnotetext{
${ }^{324}$ Holtzmann, ed., Die Chronik des Bischofs Thietmar, 520. "Episcopus in hiis partibus constituti ab eorum potentia sunt nimium depressi; et nos eorum procuratores, si contra Deum et iusticiam eius voluntati eorum in cunctis satisfacimus, honorem et aliquam utilitatem habemus; sin autem, contempnimur et, sicut nobis nullus aut regnet aut imperet dominus, depredamur." (English) Warner, Ottonian Germany, 376-377.

${ }^{325}$ Ibid., 344: "Nec preterire possum, quod miserabile nimis predicto comiti ibidem accidit. Nos omnes-nec aliquem excipere valeo-vice amicorum hostes huic fuimus exceptisque dumtaxat mancipiis omnia consumpsimus et quaedam igne. Huius rei nec rex ultor seu defensor fuit." (English) Warner, Ottonian Germany, 276.

${ }^{326}$ Ibid., 335: "Nostri predecessores suis prelatis semper fideles optimi milites in extraneis nacionibus non in suis visceribus armis seviebant." (English) Warner, Ottonian Germany, 271.

${ }^{327}$ Ibid., 72: "Tunc iste confortatus in Domino post longum mutui agonis luctamen victor hostem prostravit et inter multas itineris asperitates incolomis notos pervenit ad fines." (English) Warner, Ottonian Germany, 112.

${ }^{328}$ Ibid., 6: “...cum missam caneret, hostili circumvallatus agmine, premissisque omnibus per martirium suimet consociis, semet ipsum optulit..." (English) Warner, Ottonian Germany, 69.
} 
that readers would recognize that their actions on the battlefield, even during single combat, were approved by God.

Finally, evidence from the Chronicon shows the amount of agency that clergy and bishops had when conducting violence and warfare. Specifically, Thietmar's praise for Bishop Henry of Würzburg and Abbot Erkanbald of Fulda, who exercised their "love for Christ ${ }^{\text {"329 }}$ over secular concerns, demonstrate that even when acting under orders from their royal sovereign, there was still opportunity for individual clergy to act according to their own principles. By restraining their behavior and only tearing down Schweinfurt's fortifications instead of destroying the burg, the bishop and abbot showed that violence and warfare were not always a foregone conclusion, and that some clergy were able to temper their behavior in ways that others were not. Thietmar recognized this fact in these two clergy, and praised them for it. This incident stands in stark contrast to Thietmar's participation in pillaging his friend Margrave Gero's lands, where he accepted responsibility for his actions. These examples show how a militant bishop viewed clerical warfare while demonstrating the level of agency that bishops and clergy possessed. They also remind us that while historical figures were people who operated within contexts that contained social norms and mores, they ultimately made their own decisions.

Bishop Thietmar of Merseburg was more than just a spiritual leader, he was also a territorial lord, complete with all the secular obligations that attended this position. This condition resulted in a complex duality between secular and spiritual roles which scholars have characterized in a variety of ways. One is recognizing that many bishops sometimes behaved violently, either to defend their diocese from threats or to serve their own local

${ }^{329}$ Warner, Ottonian Germany, 231. 
or regional political needs. ${ }^{330}$ In this capacity, militant bishops contributed to or fueled the age's violence, even while attempting to temper it among lay nobles. ${ }^{331}$ Secondly, some scholars have called the secular and spiritual positions complementary, which meant that these men benefited from intertwining them. ${ }^{332}$ To press the point further, one scholar viewed the goal of some bishops as combining the military and spiritual realms in order to provide better pastoral care for the members of their flock. ${ }^{333}$ Thietmar of Merseburg is an example of a bishop who fits this category. By praising militant bishops and clergy for their prowess on the battlefield, for their ability to defend their territories, or for their acts of justified violence against transgressors, Thietmar supported the notion that bishops in tenth- and early eleventh-century Germany did indeed benefit from operating in a combined secular and spiritual modality. In his accounts of clerical warfare and violence, Thietmar regularly failed to emphasize the spiritual role his subjects played in their military capacity. On the contrary, the times that his subjects displayed spiritual behavior while in these roles were often instances where Thietmar praised their actions or called them martyrs. These were fairly rare occurrences according to Thietmar.

After examining Thietmar of Merseburg, we now have a better idea of how a German bishop rationalized clerical warfare, which is a starting point for further studies on this topic. Thietmar's viewpoints on militant clergy can be used in comparative studies, both with his contemporaries, and in a chronology of clerical warfare leading up to the crusades. This effort could be used to flesh out Carl Erdmann's study on the

\footnotetext{
${ }^{330}$ Fichtenau, Living in the Tenth Century, 206.

${ }^{331}$ Leyser, "Early Medieval Warfare," 32-33.

${ }^{332}$ Nightingale, "Bishop Gerard of Toul (963-94) and Attitudes to Episcopal Office," 41.

${ }^{333}$ Ramseyer, "Pastoral Care as Military Action: The Ecclesiology of Archbishop Alfanus I of Salerno (1058-1085)," 207.
} 
Church's appropriation of violence leading up to the crusades, and determine how individual clergy contributed to, or resisted, this development. Comparative studies could be done between Thietmar of Merseburg as a frontier bishop and other contemporary clergy who were operating in more urban, settled areas. Thanks to Thietmar's accounts of preaching violence and martyrdom, more work could also be done on conditions and outcomes of preaching and conversion activities along the German frontier, and local responses. Finally, Thietmar drew from a plethora of sources for his lengthy Chronicon. Further work is needed examining the sources Thietmar used, and how they influenced him: his attitudes, philosophy, and worldview.

Thietmar of Merseburg's Chronicon is a rich, revealing, and grand historical source in an era with very few voices. He wrote his Chronicon in order to capture the deeds of the Ottonian kings and the rebirth of his diocese of Merseburg. The Chronicon was written by a man who received a high level of education for the time, at institutions known for their quality instruction. Thietmar was born into a prominent, well-connected political family, and was raised amidst that legacy. He was also a bishop, and as such expected to perform a variety of ecclesiastical duties; namely, the protection and salvation of his flock. As a territorial lord, he also had responsibilities that included serving his king in a military capacity when called upon. This should remind us that historical figures are also people; they are placed in scenarios, within contexts that contain guidelines, social norms and mores, and ultimately, make their own decisions. Tenth- and early eleventh-century Germany-the 'Age of Iron'-was filled with people struggling to make sense of their conditions and acting according to social norms and expectations from weak, yet burgeoning, institutions. Studying the macro view of this age 
and its social context is a starting point to unlocking it. But understanding individual bishops as both secular and spiritual figures allows us to appreciate this context more fully and realistically. Realizing that Thietmar of Merseburg justified clerical violence based on intent and circumstances will help us attribute more agency to these individuals and their sometimes violent actions. 


\section{Bibliography}

Arnold, Benjamin. "Episcopal Authority Authenticated and Fabricated: Form and Function in Medieval German Bishops' Catalogues." In Warriors and Churchmen in the High Middle Ages: Essays Presented to Karl Leyser. Edited by Karl Leyser and Timothy Reuter, 63-79. London: Hambledon Press, 1992.

—. "German Bishops and their Military Retinues in the Medieval Empire." German History 72, no. 2 (1989) 161-183.

—. German Knighthood, 1050-1300. Oxford: Clarendon Press, 1985.

Bachrach, Bernard. "Klerus und Krieg im früheren Mittelalter. Untersuchungen zur Rolle der Kirche beim Aufbau der Königsherrschaft (Book Review)." The Catholic Historical Review 60, no. 3 (1974): 478-79.

Bachrach, David Stewart. "Milites and Warfare in Pre-Crusade Germany." War in History 22, no. 3 (2015): 298-343.

—. "The Military Organization of Ottonian Germany, c. 900-1018: The Views of Bishop Thietmar of Merseburg." The Journal of Military History 72, no. 4 (2008): 1061-1088.

- Religion and the Conduct of War, c. 300-1215. Warfare in History. Woodbridge, UK: Boydell Press, 2003.

Bloch, Marc. Feudal Society. Trans. by Routledge Classics. Hoboken: Taylor and Francis, 2014.

Blumenthal, Uta-Renate. The Investiture Controversy. Church and Monarchy from the Ninth to the Twelfth Century. Middle Ages Series. Philadelphia: University of Pennsylvania Press, 1988.

Brown, Warren, and Piotr Górecki, eds. Conflict in Medieval Europe: Changing Perspectives on Society and Culture. Aldershot: Ashgate, 2003.

Brown, Warren, and Piotr Górecki. "What Conflict Means: The Making of Medieval Conflict Studies in the United States, 1970-2000." In Conflict in Medieval Europe: Changing Perspectives on Society and Culture. Edited by Warren C. Brown and Piotr Górecki, 1-35. Aldershot: Ashgate, 2003.

Clarke, Peter. "The Medieval Clergy and Violence: An Historiographical Introduction." In Violence and the Medieval Clergy. Edited by Gerhard Jaritz and Ana Marinković, 3-16. CEU Medievalia; 16. Budapest: Central European University Press, 2011. 
Davies, Wendy, and Paul Fouracre. "Conclusion: Property and Power in Early Medieval Europe." In Property and Power in the Early Middle Ages. Edited by Wendy Davies and Paul Fouracre, 245-271. New York: Cambridge University Press, 1995.

- eds. Property and Power in the Early Middle Ages. New York: Cambridge University Press, 1995.

DeVries, Kelly. "God and Defeat in Medieval Warfare: Some Preliminary Thoughts." In The Circle of War in the Middle Ages: Essays on Medieval Military and Naval History. Edited by Donald J. Kagay and L. J. Andrew Villalon, 87-97. Warfare in History. Woodbridge: Boydell Press, 1999.

Duggan, Lawrence G. Armsbearing and the Clergy in the History and Canon Law of Western Christianity. Woodbridge, UK: Boydell and Brewer, 2013.

Eldevik, John. "Bishops in the Medieval Empire: New Perspectives on the Church, State and Episcopal Office." History Compass 9, no. 10 (2011): 776-90.

Erdmann, Carl. The Origin of the Idea of Crusade. Trans. Marshall W. Baldwin and Walter Goffart. Princeton: Princeton University Press, 1977.

Fichtenau, Heinrich. Living in the Tenth Century: Mentalities and Social Orders. Trans. by T. Patrick Geary. Chicago: University of Chicago Press, 1991.

Freed, John B. "Nobles, Ministerials, and Knights in the Archdiocese of Salzburg." Speculum: A Journal of Medieval Studies 62 (1987): 575-611.

—. "Reflections on the Medieval German Nobility." The American Historical Review 91, no. 3 (1986): 553-75.

Halsall, Guy. Violence and Society in the Early Medieval West. Woodbridge: Boydell, 2002.

Holtzmann, Robert, ed. Die Chronik des Bischofs Thietmar von Merseburg und ihre Korveier Überarbeitung. Monumenta Germaniae Historica. Scriptores Rerum Germanicarum. Nova Series; 9. Berlin: Weidmannsche Buchhandlung, 1935.

Howe, John. "Re-Forging the 'Age of Iron' Part I: The Tenth Century as the End of the Ancient World?" History Compass 8, no. 8 (2010): 866-887.

—. "Re-Forging the 'Age of Iron' Part II: The Tenth Century in a New Age?" History Compass 8, no. 9 (2010): 1000-1022.

Jaeger, C. Stephen. "The Courtier Bishop in Vitae from the Tenth to the Twelfth Century." Speculum: A Journal of Medieval Studies 58, no. 2 (1983): 291-325. 
Kagay, Donald J., and L. J. Andrew Villalon, eds. The Circle of War in the Middle Ages: Essays on Medieval Military and Naval History. Warfare in History. Woodbridge: Boydell Press, 1999.

Körntgen, Ludger, and Dominik Wassenhoven, eds. Patterns of Episcopal Power: Bishops in Tenth and Eleventh Century Western Europe = Strukturen Bischöflicher Herrschaftsgewalt im westlichen Europa des 10. und 11. Jahrhunderts. PrinzAlbert-Forschungen, bd. 6 = Prince Albert Research Publications, 6. Berlin: De Gruyter, 2011.

Kotecki, Radosław, Jacek Maciejewski, and John S. Ott, eds. Between Sword and Prayer: Warfare and Medieval Clergy in Cultural Perspective. Explorations in Medieval Culture, v. 3. Boston: Brill, 2018.

Kotecki, Radosław, Jacek Maciejewski, and John S. Ott. "The Medieval Clergy and War: A Historiographical Introduction." In Between Sword and Prayer: Warfare and Medieval Clergy in Cultural Perspective, edited by Kotecki, Radosław, Jacek Maciejewski, and John S. Ott, 1-23. Explorations in Medieval Culture, v. 3. Boston: Brill, 2018.

Lerner, Robert E. "Thietmar von Merseburg." In Dictionary of the Middle Ages. Edited by Joseph R. Strayer, 27-28. Vol. 12 New York: Scribner, 1982.

Leyser, Karl. Communications and Power in Medieval Europe: The Carolingian and Ottonian Centuries, edited by Timothy Reuter. London: Hambledon Press, 1994.

—_. "Early Medieval Warfare." In Communications and Power in Medieval Europe: The Carolingian and Ottonian Centuries, edited by Timothy Reuter, 29-50. London: Hambledon Press, 1994.

—. Medieval Germany and Its Neighbours, 900-1250. History Series, v. 12. London: Hambledon Press, 1982.

—. 'Lippelt, 'Thietmar von Merseburg Reichshischof und Chronist' (Book Review)," English Historical Review 93, no. 366 (1978): 109-110.

Leyser, Karl, and Timothy Reuter, eds. Warriors and Churchmen in the High Middle Ages: Essays Presented to Karl Leyser. London: Hambledon Press, 1992.

McKitterick, Rosamond. "The Church.” In The New Cambridge Medieval History, Volume 3 c. $900-$ c. 1024, edited by Timothy Reuter, 130-162. Cambridge: Cambridge University Press, 1999.

—. The Frankish Kingdoms under the Carolingians, 751-987. London: Longman, 1983. 
Nightingale, John. "Bishop Gerard of Toul (963-94) and Attitudes to Episcopal Office." In Warriors and Churchmen in the High Middle Ages: Essays Presented to Karl Leyser, edited by Karl Leyser and Timothy Reuter, 41-62. London: Hambledon Press, 1992.

Ott, John S., and Anna Trumbore Jones, eds. The Bishop Reformed: Studies of Episcopal Power and Culture in the Central Middle Ages. Church, Faith, and Culture in the Medieval West. Aldershot: Ashgate, 2007.

Ott, John S., and Anna Trumbore Jones. "Introduction: The Bishop Reformed.” In The Bishop Reformed: Studies of Episcopal Power and Culture in the Central Middle Ages, edited by John S. Ott and Anna Trumbore Jones, 1-20. Church, Faith, and Culture in the Medieval West. Aldershot: Ashgate, 2007.

Prinz, Friedrich. Klerus und Krieg im Frühmittelalter: Untersuchungen zur Rolle der Kirche beim Aufbau der Königsherrschaft. Monographien zur Geschichte des Mittelalters, 2. Stuttgart: Anton Hiersemann, 1971.

Ramseyer, Valerie. "Pastoral Care as Military Action: The Ecclesiology of Archbishop Alfanus I of Salerno (1058-1085)." In The Bishop Reformed: Studies of Episcopal Power and Culture in the Central Middle Ages, edited by John S. Ott and Anna Trumbore Jones, 189-208. Aldershot: Ashgate, 2007.

Reuter, Timothy. "A Europe of Bishops: The Age of Wulfstan of York and Burchard of Worms." In Patterns of Episcopal Power: Bishops in Tenth and Eleventh Century Western Europe = Strukturen Bischöflicher Herrschaftsgewalt im westlichen Europa des 10. und 11. Jahrhunderts, edited by Ludger Körntgen and Dominik Wassenhoven, 17-38. Prinz-Albert-Forschungen, bd. 6 = Prince Albert Research Publications, 6. Berlin: De Gruyter, 2011.

—. Germany in the Early Middle Ages, c. 800-1056. Longman History Of Europe. London: Longman, 1991.

—. "The 'Imperial Church System' of the Ottonian and Salian Rulers: A Reconsideration." In Medieval Polities and Modern Mentalities, edited by Janet L. Nelson, 325-354. Cambridge: Cambridge University Press, 2006.

—. "Introduction: Reading the Tenth Century." In The New Cambridge Medieval History, Volume 3 c. $900-$ c. 1024, edited by Timothy Reuter, 1-24. Cambridge: Cambridge University Press, 1999.

—. "Peace-Breaking, Feud, Rebellion, Resistance: Violence and Peace in the Politics of the Salian Era." In Medieval Polities and Modern Mentalities, edited by Janet L. Nelson, 355-388. Cambridge: Cambridge University Press, 2006. 
- ed. The New Cambridge Medieval History, Volume 3 c. 900 - c. 1024. Cambridge: Cambridge University Press, 1999.

—_. "The Ottonians and Carolingian Tradition." In Medieval Polities and Modern Mentalities, edited by Janet L. Nelson, 268-283. Cambridge: Cambridge University Press, 2006.

—. "Thietmar, bishop of Merseburg." In Encyclopedia of Historians and Historical Writing, edited by Kelly Boyd, 1183-84. Vol. 2. Chicago: Fitzroy Dearborn, 1999.

Russell, Frederick H. The Just War in the Middle Ages. Cambridge Studies in Medieval Life and Thought; 3rd Ser., v. 8. Cambridge: Cambridge University Press, 1975.

Schieffer, Rudolf. "Der ottonische Reichsepiskopat zwischen Königtum und Adel." Frühmittelalterliche Studien 23 (1989): 291-301.

Skinner, Patricia, and Henry Mayr-Harting, eds. Challenging the Boundaries of Medieval History: The Legacy of Timothy Reuter. Studies in the Early Middle Ages. Turnhout, Belgium: Brepols, 2009.

Tellenbach, Gerd. The Church in Western Europe from the Tenth to the Early Twelfth Century. Cambridge Medieval Textbooks. Cambridge: Cambridge University Press, 1993.

“Thietmar of Merseburg." In The Oxford Dictionary of the Middle Ages. Oxford: Oxford University Press, 2010.

http://www.oxfordreference.com/view/10.1093/acref/9780198662624.001.0001/acre f-9780198662624-e-5654.

Warner, David A. "Reading Ottonian History: The Sonderweg and Other Myths." In Challenging the Boundaries of Medieval History: The Legacy of Timothy Reuter, edited by Patricia Skinner and Henry Mayr-Harting, 81-114. Studies in the Early Middle Ages. Turnhout, Belgium: Brepols, 2009.

-. Ottonian Germany: The Chronicon of Thietmar of Merseburg. Manchester Medieval Sources Series. Manchester: Manchester University Press, 2000.

—_. "Thietmar of Merseburg on Rituals of Kingship." Viator 26 (1995): 53-76.

Wickham, Chris. The Inheritance of Rome. Illuminating the Dark Ages, 4001000. London: Penguin, 2009. 